\title{
CAN SEVERE FISCAL CONTRACTIONS BE EXPANSIONARY? \\ TALES OF TWO SMALL EUROPEAN COUNTRIES
}

Francesco Giavazzi

Marco Pagano

Working Paper No. 3372

NATIONAL BUREAU OF ECONOMIC RESEARCH

1050 Massachusetts Avenue

Cambridge, MA 02138

May 1990

We wish to thank Olivier Blanchard, Allan Drazen, Alberto Alesina, Vittorio Grilli, Tullio Jappel1i, Mervyn King, Luigi Spaventa, Niels Thygesen and participants to the 1990 NBER Macroeconomics Annual Conference, for helpful suggestions and advice. Anders Moller Christensen and Dan Knudsen of Danmarks Nationalbank have provided a wealth of data and illuminating discussions on the Danish economy. Michael Moore of the Central Bank of Ireland has spent long hours discussing with us the Irish experience. We also thank Gianluca Squassi for providing competent and enthusiastic research assistance. This paper is part of NBER's research program in International studies. Any opinions expressed are those of the authors and not those of the National Bureau of Economic Research. 
NBER Working Paper \#3372

May 1990

CAN SEVER FISCAL CONTRACTIONS BE EXPANSIONARY?

TALES OF TWO SMALL EUROPEAN COUNTRIES

\section{ABSTRACT}

According to conventional wisdom, a fiscal consolidation is 1 ikely to contract real aggregate demand. It has of ten been argued, however, that this conclusion is misleading as it neglects the role of expectations of future policy: if the fiscal consolidation is read by the private sector as a signal that the share of government spending in GDP is being permanently reduced, households will revise upwards their estimate of their permanent income, and will raise current and planned consumption.

Only the empirical evidence can sort out which of these two contending views about fiscal policy is more appropriate -- i.e how often the contractionary effect of a fiscal consolidation prevails on its expansionary expectational effect. This paper brings new evidence to bear on this issue drawing on. the European exercise in fiscal rectitude of the 1980s, and focusing, in particular, on its two most extreme cases -- Denmark and Ireland.

We find that at least in the experience of these two countries the expectations' view has a serious claim to empirical relevance.

Francesco Giavazzl

Departemento di Scienze Economiche Universita di Bologna

Strada Maggiore 45

I-45100, Bologna

ITALY
Marco Pagano

Univerista' di Napoli

via Catullo 64

I-80122, Napol1

ITALY 


\section{Budget cuts in Europe: contractionary or expansionary ?}

In most European countries, the high real interest rates of the early 1980s combined with the large stock of public debt inherited from the 1970 s to create a potentially explosive debt problem. As governments started to tackle the problem with contractionary fiscal policies, public officials and economists voiced different beliefs about the likely effects of these measures. In Denmark, for example, while the Parliament was discussing a package of severe budget cuts in January 1983, the Ministry of Finance anticipated that the fiscal contraction would "dampen private consumption", in truly Keynesian fashion:

\footnotetext{
"Curtailing domestic demand will lead to a temporary increase in unemployment [...] and will have a dampening effect on business fixed investment. [...] It is to be expected that the Government's policy will secure a marked reduction in the deficit on the current account of the balance of payments" (Danish Ministry of Finance, 1983).
}

The German Council of Economic Experts, on the contrary, proposed the view that the impact of budget deficits on demand was predominantly negative (Sachverstandigenrat 1981), so that fiscal retrenchment should be seen as the premise for an expansion, rather than a recession. In their retrospective account of the German fiscal consolidation, Fels and Froehlich (1987) summarize this anti-Keynesian view:

\footnotetext{
"fiscal consolidation had a benign impact on expectations ... [An] important explanation is the way fiscal consolidation was actually brought about. Rather than raising taxes, the deficit was reduced by keeping a lid on expenditure growth ... By absorbing a smaller share of GNP, the public sector made room for the private sector to expand" ( $p$. 184-5).
}

In a later reappraisal of that experience, Hellwig and Neumann (1987) take an eclectic stance, merging the Keynesian and the "German" views on budget cutting:

\footnotetext{
"According to conventional wisdom, any policy of consolidation is likely to contract real aggregate demand in the shorter run. This Keynesian conclusion, however, is misleading as it neglects the role of expectations. A more adequate analysis differentiates between the direct demand effect of
} 
cutting the growth of government expenditure and the indirect effect of an induced change in expectations. The direct demand impact of slower public expenditure growth is clearly negative ... The indirect effect on aggregate demand of the initial reduction in expenditure growth occurs through an improvement in expectations if the measures taken are understood to be part of a credible medium-run program of consolidation, designed to permanently reduce the share of government in GDP ... [and thus] taxation in the future" (p. 137-8).

Only the empirical evidence can sort out which of these two contending views about fiscal policy is more appropriate -- or, in Hellwig and Neumann's terms, how often the contractionary Keynesian effect of a spending cut prevails on its expansionary expectational effect. The aim of this paper is precisely to bring new evidence to bear on this issue: we draw on some of the data generated by thr European exercise in fiscal rectitude of the 1980s, and focus on its two most extreme cases -- Denmark and Ireland.

The European experience is especially rich, not only because the severity of budget cutting varied widely across countries, but also because the relative contributions of taxes and spending to the final outcome were quite different. Figure 1 shows that some countries were able to implement a very substantial turnaround of the budget over the years 1981 to 1989 (for the UK, that was an "early starter", the interval is 1979-89). In Ireland, Denmark; Sweden, Belgium and the U.K. the budgetary position of the public sector improved by amounts ranging from 6.6 to $3 \pi$ of GDP. In others, like Germany and France, the improvement in the budget was negligible, while in the Netherlands the deficit actually increased. The contribution of taxes was relatively more important in Ireland, Denmark, Sweden and Belgium, while most of the action in Germany came from cuts in current spending. In the Netherlands the effect of reduced government expenditure was more than offset by tax cuts; Italy and Spain, instead, raised spending while relying entirely on tax revenue to improve the 


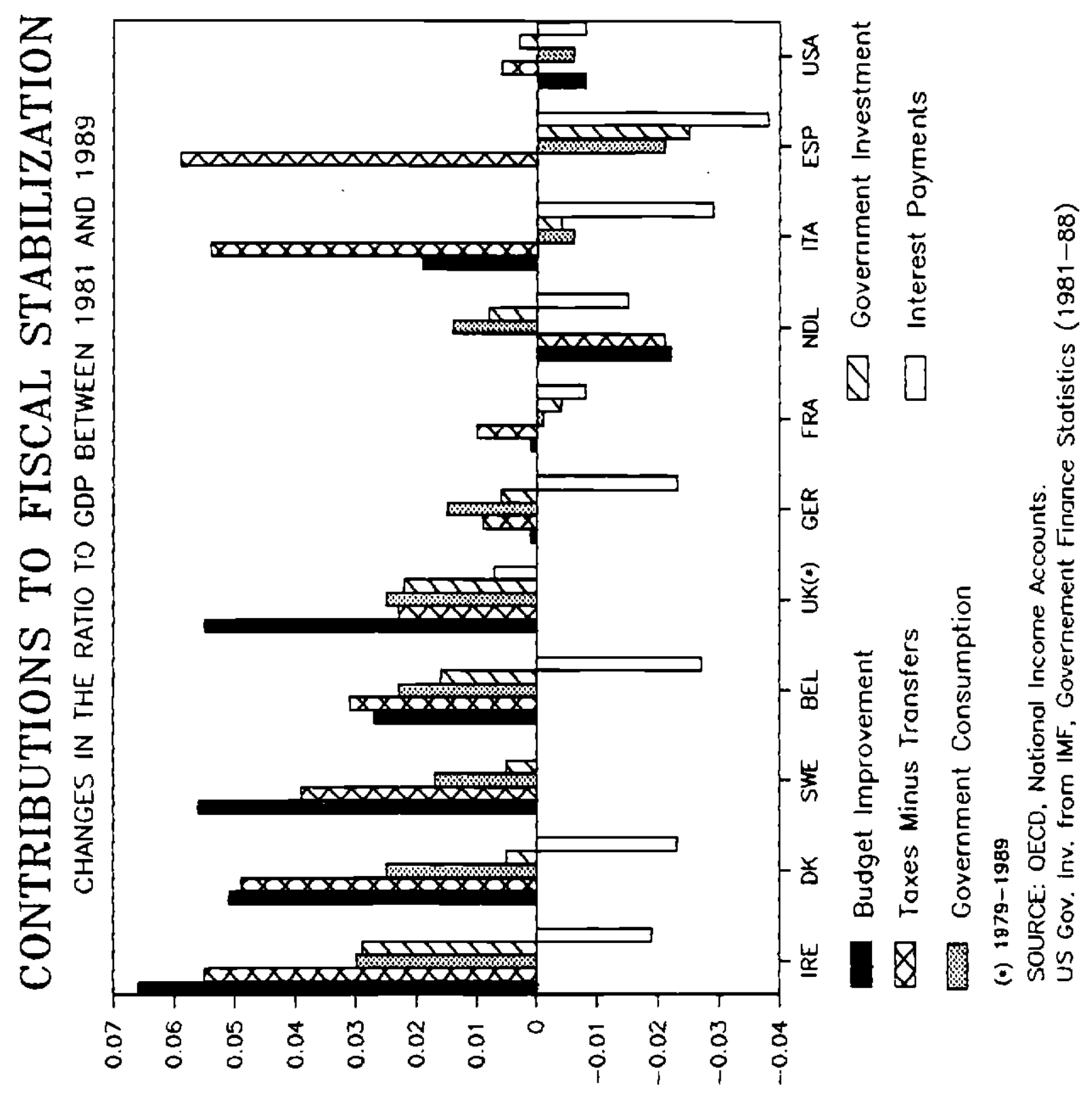

FIGURE 1 
budget -- a policy that resembles that of the United States.

Table 1 describes the response of real private consumption to these fiscal shocks. The regressions in the table are not to be seen as estimates of a structural model, but rather as a way to summarize the main correlations in the data. In raw (1) the regressors are a constant, cyclically-corrected taxes net of transfers and subsidies 1 , government consumption, and a proxy for the international cycle; in regressions (2) and (3) real money balances are also added to the $l$ ist of regressors. All variables (except for the international cycle proxy) are measured relative to potential GDP.

Taxes appear to correlate negatively with private consumption: in regressions (1) and (2), where the coefficients on the policy variables are constrained to be the same across countries, the coefficient on taxes is negative and significant; and it is generally negative (though of ten imprecisely estimated) also in regression (3), where it is left unconstrained across countries. Real money balances are positively correlated with private consumption and are often significant.

So far, the data are consistent with the predictions of a Keynesian textbook. However, increases in government spending display a negative relationship with consumption. This result hides considerable cross-country variation: the unconstrained estimates in regression ( 3 ), show that this negative correlation is strong and significant in some of the countries where, according to figure 1 , there were sharp cuts in public spending -- Ireland, the UK and the Netherlands. In no country the coefficient of public spending is positive and significant.

1 The cyclical correction of net taxes is intended to el iminate most of the endogeneity of taxes. Figures for cyclically-corrected taxes were provided by the EC: their construction is described in European Economy, no. 22, 1984 


\section{Table 1}

Exfects of fiscal consolidation on private consumption a

(regression on stacked data for 10 countries, 1973-89)

$\begin{gathered}\text { Lagged } \\ C / Y^{*}\end{gathered} \quad T^{*} / Y \quad G / Y^{*} \quad M / Y^{*} \quad \bar{R}^{2} \quad \begin{gathered}\text { Durbin's } \\ \text { sign. level }\end{gathered}$

Constrained

estimates:

$$
.86^{* *}
$$

$-.08^{\star} \quad-.23^{\star *}$

.93

$.3 E-6$

(2)

$.81^{* *}$

$-.08^{*} \quad-.18^{*} \quad .08^{* *}$

.94

$.2 \mathrm{E}-5$

Unconstrained

estimates:

(3) $.72^{* *}$

- Belgiu

.01

.59

- Denmark

$-.56$

- France

- Germany

$-.20$

$-.37$

.11

.95

.17

- Ireland

$-.34$

$-.12$

$.53^{\circ}$

- Italy

$-.01$

$-.49^{*}$

$-.42$

3.43

$-.41$

.01

- Nether

$-.63$

$-2.00^{\circ}$

- Spain

$-.44^{*}$

- Sweden

.25

$-.43$

$-.21^{*}$

- U.K.

$-.48-1.66^{\circ}$

$.27^{* 1}$

.15

.02

al1 regressions use 170 observations. In each regression the dependent variable is real private consumption $C$ as a share of potential output $Y^{*}$ (obtained by fitting an exponential trend on 1973-89 real GDP). T* are cyclically-corrected taxes net of transfers and subsidies, $G$ is public consumption. In regressions (2) and (3) the regressors include al so real money $\left(M_{2}\right)$ as a share of potential output, $(M / P) / Y^{*}$ : in (2) its coefficient is constrained to be the same for all countries, in ( 3 ) it is left unconstrained across countries. In addition, each regression includes a constant, a proxy for the international cycle (deviations of OECD growth from trend) and country dummies on these two regressors. The corresponding estimates are not reported to save space. One (two) asterisk(s) indicates that the regressor is significantly different from zero at the $10 \%(5 \%)$ level. Data sources: OECD National Income Accounts, except for $T$ that was provided by the EC. 
Figure 2 provides an alternative way to describe the relationship between spending cuts and private domestic demand. The figure plots yearly changes in the sum of private consumption and investment against changes in public spending, both measured relative to potential GDP. Data referring to the early and late 1980s are displayed separately, since in many countries the two subperiods have coincided with two distinct waves of spending cuts. Dates vary somewhat across countries to capture the years when fiscal action was more evident. The figure shows that the recession of the early 1980s was equally severe in countries that cut public spending and in those that did not. The only exception is Denmark, where the ratio of public spending to potential output fell dramatically in 1983-4, but private domestic demand grew vigorously. Instead, in the recovery of the late $1980 \mathrm{~s}$, there seems to be a negative relationship between private domestic demand and public consumption: all the observations for this subperiod 1 ie in the second and fourth quadrants of the figure (with the only exceptions of Spain and the US). Among these, Ireland stands out as the most prominent example of an expansionary cut in public spending.

This negative correlation between private and public spending can hardly be credited to an endogenous response of public spending to the cyclical behavior of income: our spending variable is defined as purchases of goods and services by the public sector, and does not include such cyclical components as transfers and subsidies. In addition, most accounts of the spending cuts that have occurred in Europe in the 1980 s point to an exogenous shift in policy, of ten

(chapter 6). 


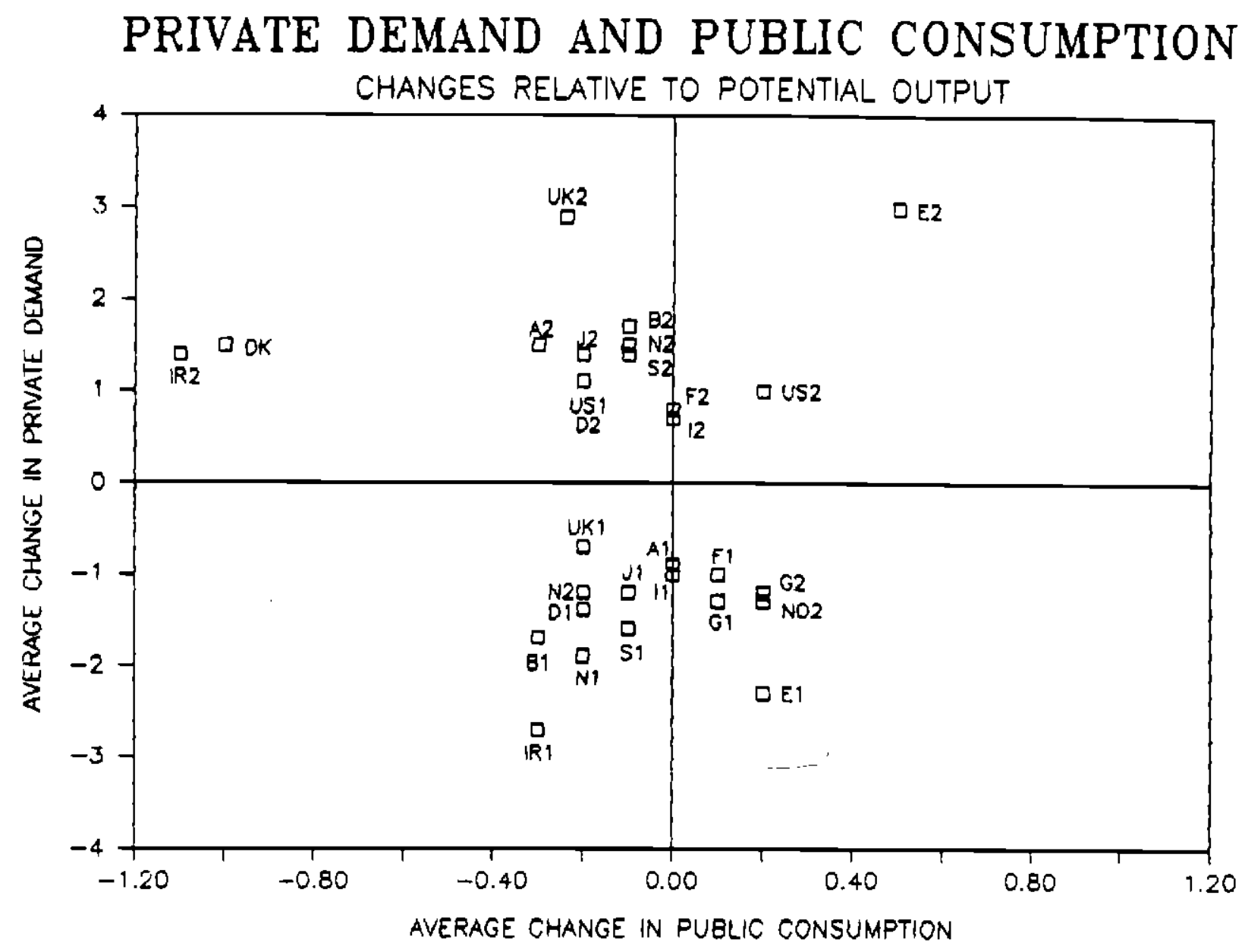

A: Austrio (1980-84, 1987-88)

B: Belgium (1980-84, 1985-89)

D: Weat Germony (1980-83, 1987-89)

DK: Denmark (1983-84)

E: Sooin $(1980-84,1985-89)$

F: France (1980-84, 1985-88)

G: Greece $(1980-84,1985-89)$

I: Italy (1980-84, 1985-88)
IR: ireland (190i-84, 1987-89)

$N$ : Netherlands (1980-84, 1985-89)

NO: Norwoy (1980-83, 1984-89)

S: Swoden (1980-83, 1986-69)

$\mathrm{J}$ : Jopan (1980-84, 1985-89)

UK: United Kingdom (1980-83, 1985-89)

US: United States (1980-83, 1984-89)

SOURCE: OECD, Nationol Income ACcounts

FIGURE 2 
associated with a change in government, rather than to an endogenous response of policy makers to an improved economic performance.

This suggests that the "German view" of negative fiscal multipliers cannot be easily dismissed -- at least for the countries where spending cuts were sharpest. According to this view, however, what should make a difference is not only the magnitude of current spending cuts, but also their expected persistence: only reductions in spending that are expected to persist can yield permanently lower taxes (Barro 1979, 1981, Feldstein 1982). To assess the expected persistence of spending cuts, we have fitted rolling univariate ARIMA processes to real government consumption series of Denmark, Ireland and Germany; the forecasts have then been used to compute the present discounted value (PDV) of predicted public consumption, that provides a measure of "permanent spending". 2 The results are reported in figure 3 . For all three countries the spending cuts of the 1980 s are associated with lower permanent spending. The drop is more sudden in Germany and in Denmark, where it is concentrated in 1981 and in 1982-84 respectively; it is more gradual. in Ireland, where it spreads almost over the entire decade.

This evidence consistently points to the experiences of Denmark and Ireland as the two most striking cases of "expansionary stabilizations" in Europe. In

2 The ARIMA processes were selected on the basis of a standard Box-Jenkins identification search. After analysing the correlation and partial autocorrelation functions of the series, we discriminated among the models on the basis of the adjusted $R^{2}$, of the Q-statistics for the first ten lags of the residuals, and of in-sanple predictive efficiency. This search was repeated for each year, after adding the corresponding observation. We have then used each estimated process to generate dynamic forecasts of public consumption for 150 steps (years) ahead at each date, and then computed the PDV of this flow using a 5 discount rate. A similar procedure is followed in Ahmed (1987). See also Seater and Mariano (1985). 


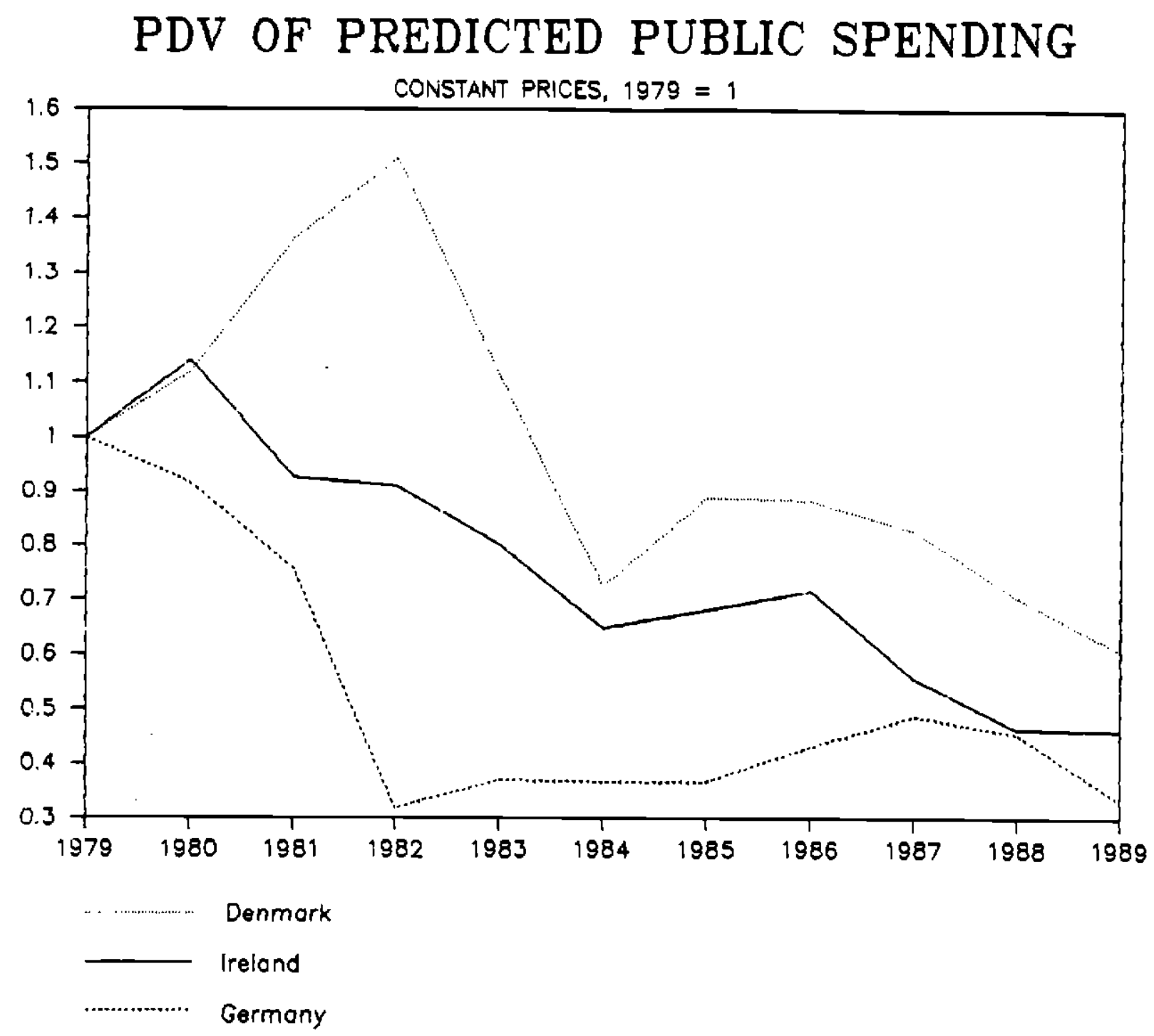

SOURCE: OECD, Notionol Income Accounts

FIGURE 3 
Denmark, the fiscal turnaround of 1982 was accompanied by an unusually strong expansion in the subsequent 4 years. In Ireland a similar outcome occurred during the 1987-89 stabilization, although a previous attempt in the early 1980 s had plunged the economy in a severe recession.

Denmark and Ireland thus offer a good testing ground to sort out the issues. Why the experience of Denmark so sharply contradicts the Kevnesian prediction about the effects of a fiscal contraction? What accounts for the early failure and later success of the Irish stabilization? The challenge posed by these experiences goes beyond the interpretation of "what really happened" in each of these countries. It offers an opportunity to identify the conditions under which severe fiscal contractions can be expansionary. This opportunity is all the more valuable because, in spite of all the discussion about the "German view" of fiscal policy, so far, to our knowledge, no evidence has been brought to bear on its empirical relevance.

We begin by reviewing the key facts about the Danish and Irish experiments (section 2), highlighting the importance of the monetary and exchange rate policies that accompanied the fiscal stabilization. Next, we discuss how the surge of private consumption can be related to these policy shocks (section 3 ). We attack the problem in two steps. First, we investigate to what extent the increase in consumption can be explained by the direct effects of policy shifts, acting via changes in current taxes, spending and asset prices. The three channels that we examine are: (i) the fall in disposable income due to the increase in current taxes; ( $i$ i) the wealth effect due to the fall in nominal and real interest rates; (iii) the reduced provision of public services to 
consumers. We then consider if the portion of the surge in consumption left unexplained by the change in current variables can be attributed to changes in expectations about future fiscal policy, along the lines of the "German view". Finally, we discuss to what extent the extraordinary performance of private investment in Denmark can be related to the stabilization package (section 4 ).

\section{Tales of two expansionary contractions}

The similarity among the stabilization policies adopted by Denmark and Ireland in the 1980 s does not reside only in the sheer magnitude of the $f$ iscal turnaround. In both cases, cuts in spending and tax increases were accompanied by a shift in the balance of political power, and by complementary monetary and exchange rate policies: after an initial devaluation, both countries pegged their currencies to the German mark, inducing a sharp monetary disinflation, and liberalized capital flows.

Each of these complementary policy moves had an important role in determining the final outcome of the stabilization: the effects of the fiscal turnaround cannot be understood if they are not placed against the backdrop of the accompanying monetary and exchange rate policies. In the 1970 s, these countries had experienced not only large budget deficits but also high rates of inflation and currency depreciation. In the stabilizations of the $1980 \mathrm{~s}$, monetary tightening was invariably the first step of the plan: Central Banks moved first, while political parties were still wrangling to gather enough social consensus in order to cut spending and raise taxes. The monetary contraction did not take place by reducing money supply growth, as in the United States and Britain in 
1979-80, but by using the exchange rate vis-à-vis the German Mark as a nominal anchor .

The sudden disinflation led to a deterioration of the financial position of the public sector, through the loss of seignorage and the increase in the real cost of servicing fixed-rate debt issued when nominal interest rates where high This heightened the sense of urgency about the need for a fiscal correction. Prompt fiscal action was required also for the success of the monetary stabilization itself, since, for the currency to be successfully pegged to the mark, the danger of future monetization of public debt had to be ruled out. A sharp reduction of the deficit could contribute to the long-run credibility of the exchange rate, providing a signal that the government would meet its obligations via tax revenue or spending cuts, and dispense with seignorage.

\section{1 Denmark}

In 1982 Danish public debt was growing rapidly (from 29 of GDP at the beginning of 1980 to $65 \%$ at the end of 1982), fuelled by high real interest rates and by large primary deficits ( $3.1 \%$ of GDP). The deficit was the result of from the government's attempt to boost demand in the middle of the world recession of the early 1980s. Despite the stimulus to aggregate demand, unemployment was 4.2 percentage points higher relative to 1979 , and the current account had worsened, bringing external debt from $17.5 \%$ to $33 \%$ of GDP over the same interval. In 0ctober 1982 long-term interest rates reached $22 \%$, while inflation was only $10 \%$ : in the presence of such astronomical real interest rates, the public started questioning the sustainability of public debt, while S\&P added a "credit watch" to the AAA rating of Danish foreign debt. 
At that time, a Conservative coalition formed a new government, and adopted a draconian program of fiscal retrenchment. Within 4 years, the turnaround in the full-employment primary budget was as large as $10 \%$ of GDP, of which $2.8 \%$ accounted for by a fall in government consumption, $0.4 \%$ by cuts in government investment, and the rest by discretionary increases in taxes net of transfers. The improvement in the actual primary budget was an even more dramatic $15.4 \%$. As a result, the debt-GDP ratio started declining.

In the monetary area the fiscal package was accompanied by the announcement that the exchange rate of the Danish kroner versus the German mark would henceforth be fixed. The credibility of the commitment to a fixed parity was enhanced by the gains of competitiveness that Denmark had attained since the inception of the EMS through a sequence of devaluations. The new government strengthened the credibility of its announcement with two signals. A few months after coming to office (in March 1983) there was a general EMS realignment: for the first time since joining the system, the Danish authorities refrained from devaluing the kroner, and thus effectively abandoned the "weak currencies' camp." 3 At the same time, they removed exchange controls: restrictions on capital inflows were abolished immediately, and controls on outflows were phased out over the subsequent two years (Thygesen 1985).

The term structure of Danish interest rates around the announcement of the stabilization, shown in figure 4 , offers some evidence on the credibility of the

3 The role of exchange rate policy in the Danish stabilization is analyzed in Christensen (1986) and Andersen and Risager (1987). 
Table 2

Key statistics on the Danisk and Irish stabilizations a

(percentage values per year)

Denmark

Ireland

Governent

1979-82 1983-86

1979-81 1982-84 1987-89

Average growth rate of:

Publ ic consumption

$4.0 \quad 0.9$

4.0

$0.7-3.7$

Public investment

$-9.4-1.1$

6.5

$-6.0-13.3$

Average change in full-empl.

$-0.3$

$-0.5$

4.1

0.4

Average change in full-empl.

deficit as $\%$ of GDP

$1.8-1.8$

1.3

$-1.8$

$-1.9$

Public debt as $\%$ of GDP

$10.2 \quad 0.0$

4.0

$6.8-0.8$

\section{Private sector}

Average growth rate of:

Disposable income

Consumption

Business investment

Exports

GDP
$2.6-0.3$

$\begin{array}{ll}-0.8 & 3.7\end{array}$

$\begin{array}{ll}-2.9 & 12.7\end{array}$

$6.0 \quad 3.2$

$1.3 \quad 3.6$
1.0

2.2

7.2

4.9

$2.7 \quad 0.0$

$-1.2$

$-1.2$

$-4.7$

10.8

3.6

6.7

11.0

3.7

Lons-tere interest rates (period averages)

$$
\text { 1979-82 1983-86 1979-81 } 1982-4 \quad 1986-7 \quad 1988-9
$$

Nominal

Real (ex ante)b
$19.6 \quad 12.5$

$6.7 \quad 3.3$
15.

$0.5-0.3$

11. 1

5.2

8.9

4.4

a Source: All data are drawn from OECD National Income Accounts, except for the cyclically-adjusted budget balance, described in footnote 1 , and for nominal interest rates, that for Denmark are average yields on long-term government bonds from European Economy, and for Ireland are yields on 5-years government bonds from the Quarterly Bulletin of the Central Bank of Ireland.

- The methology used to construct ex-ante real rates is described in footnote 5 . 


\section{DENMARK: THE TERM STRUCTURE 1982-83}

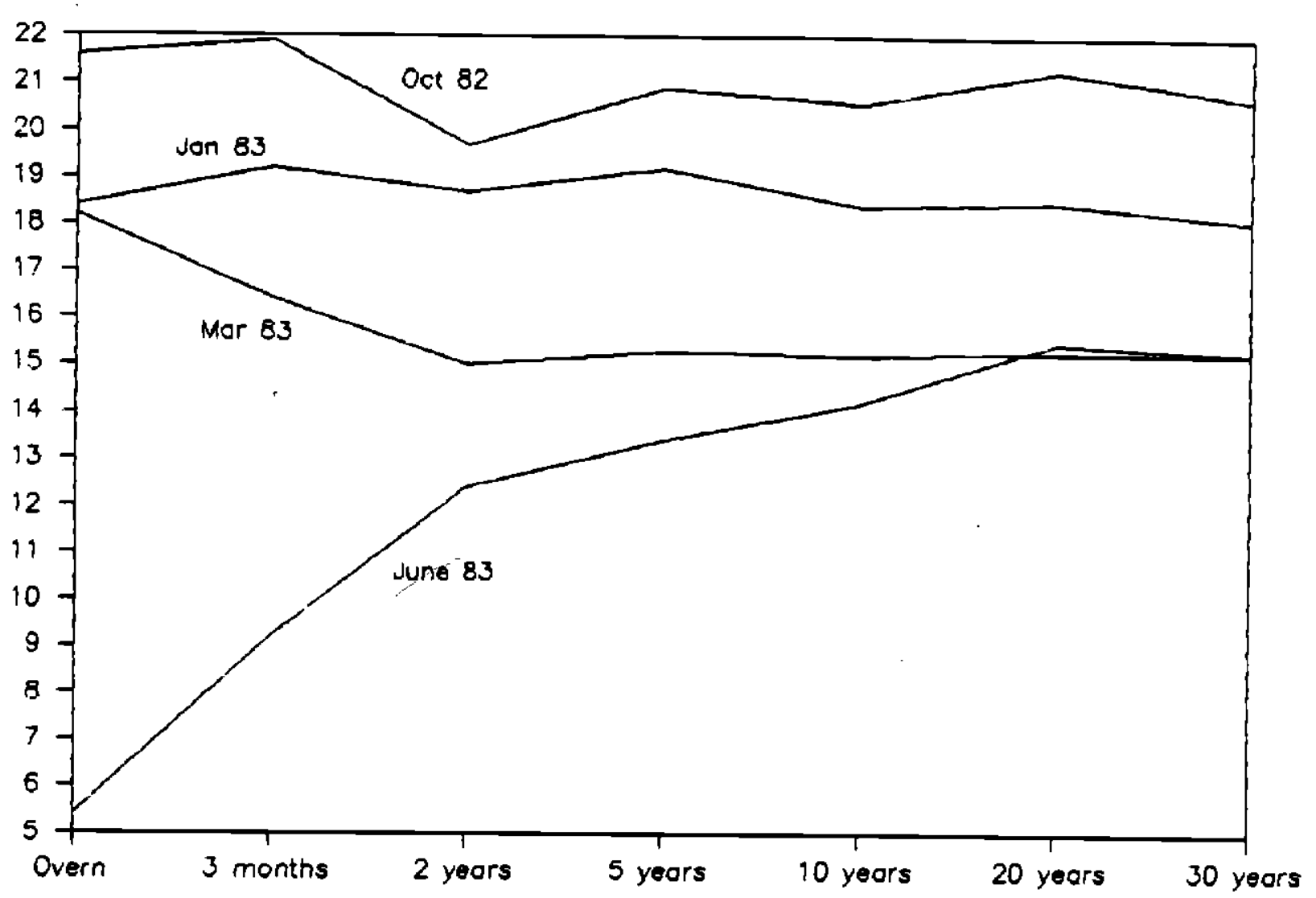

SOURCE: Danmarks Nationalbank, Monetary Review

FIGURE 4 
new policy. When the government passed the test of the March 1983 realignment, the long term interest rate fell sharply -- by $5.5 \%$ in two months. (The gap with German rates, however, did not actually close: as late as 1986, the differential was still $4.6 \%$ ).

As mentioned in section 1, rather than reducing aggregate demand and income, the severe Danish contraction was accompanied by an average 8 rowth of $3.6 \%$ in real GDP over the years from 1983 to 1986. Growth was driven by domestic demand: private consumption increased rapidly in spite of the reduction of disposable income due to higher taxes, and investment boomed spectacularly (see table 2).

In the econometric model of the Danish Central Bank, the increase in consumption appears to be remarkably well tracked by its correlation with wealth (Christensen 1988). In fact, as shown by figure 5, consumption and wealth reacted with striking simultaneity to the announcement of the stabilization plan in the fall of 1982. The increase in the market value of wealth was mostly due to the increase in house prices. Figures $6 \mathrm{~A}$ and $6 \mathrm{~B}$ suggest that the jump in the value of equity (houses and shares) was related to the sharp fall in real interest rates that occurred in early 1983, at the time of the EMS realignment. 5 As shown in figure $5 b$, also public debt played a role in the increase of households' wealth. As we show in Section 3, there were two reasons for the

4 The data for total wealth, houses and government bonds, shown in figures $5 a$ and $5 b$, are at market value and constant prices.

5 We constructed ex ante real rates by deflating nominal rates using the forecast for inflation from a VAR for inflation, short and long nominal interest rates, on quarterly data from 1970 to 1988. The VAR used to compute the forecast was re-estimated each year. The horizon over which the forecast is taken is synchronized with the maturity of the nominal interest rate. 


\section{DENMARK: WEALTH AND PRIVATE CONSUMPTION}

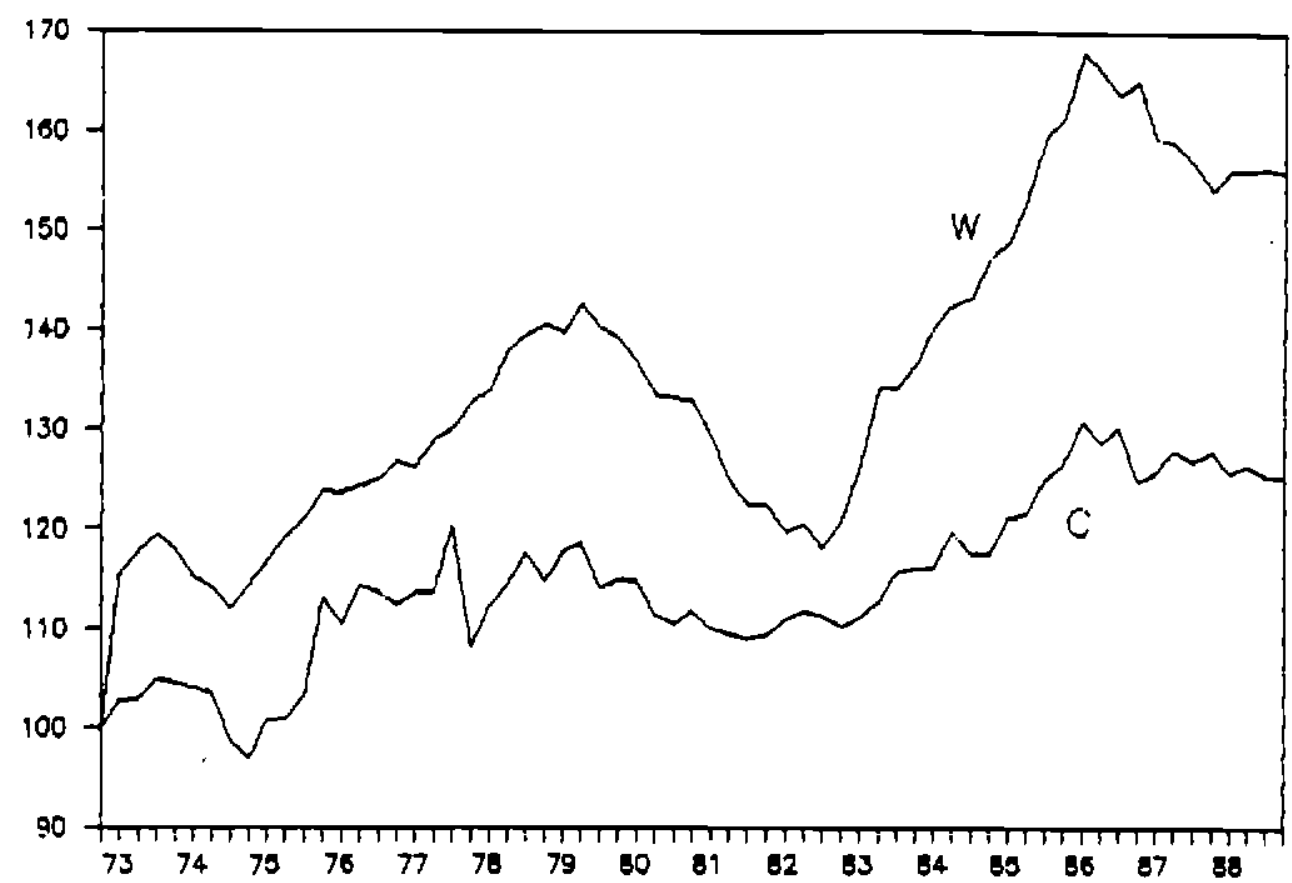

Indices $1972: 4=100$

FIGURE 50

DENMARK: COMPONENTS OF REAL PRIVATE WEALTH

(Billions Kr. of 1971:1)

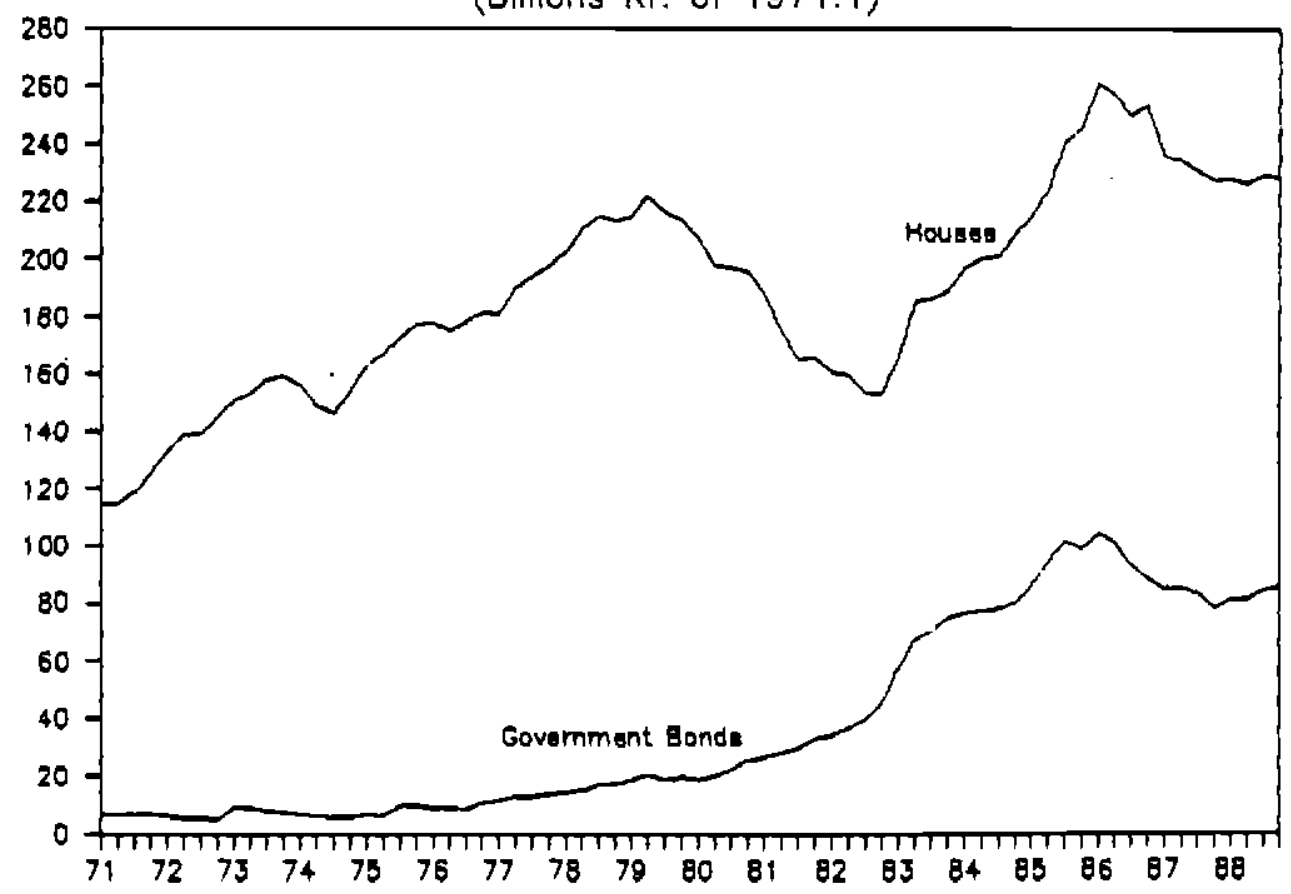

FIGURE 5b 
DENMARK: REAL INTEREST RATE AND REAL SHARE PRICE

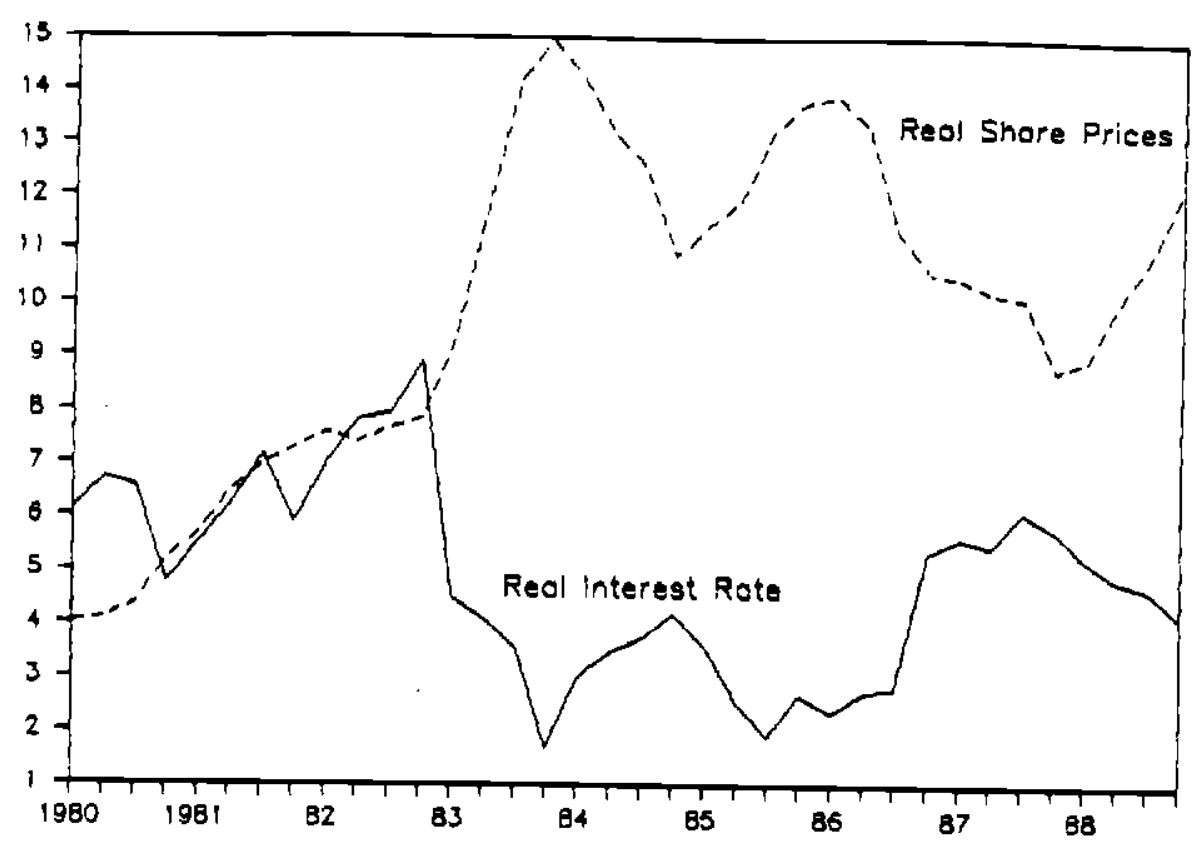

SHARE PRICE 1980:1 $=4$

FIGURE 60

DENMARK: REAL INTEREST RATE ANO REAL HOUSE PRICE

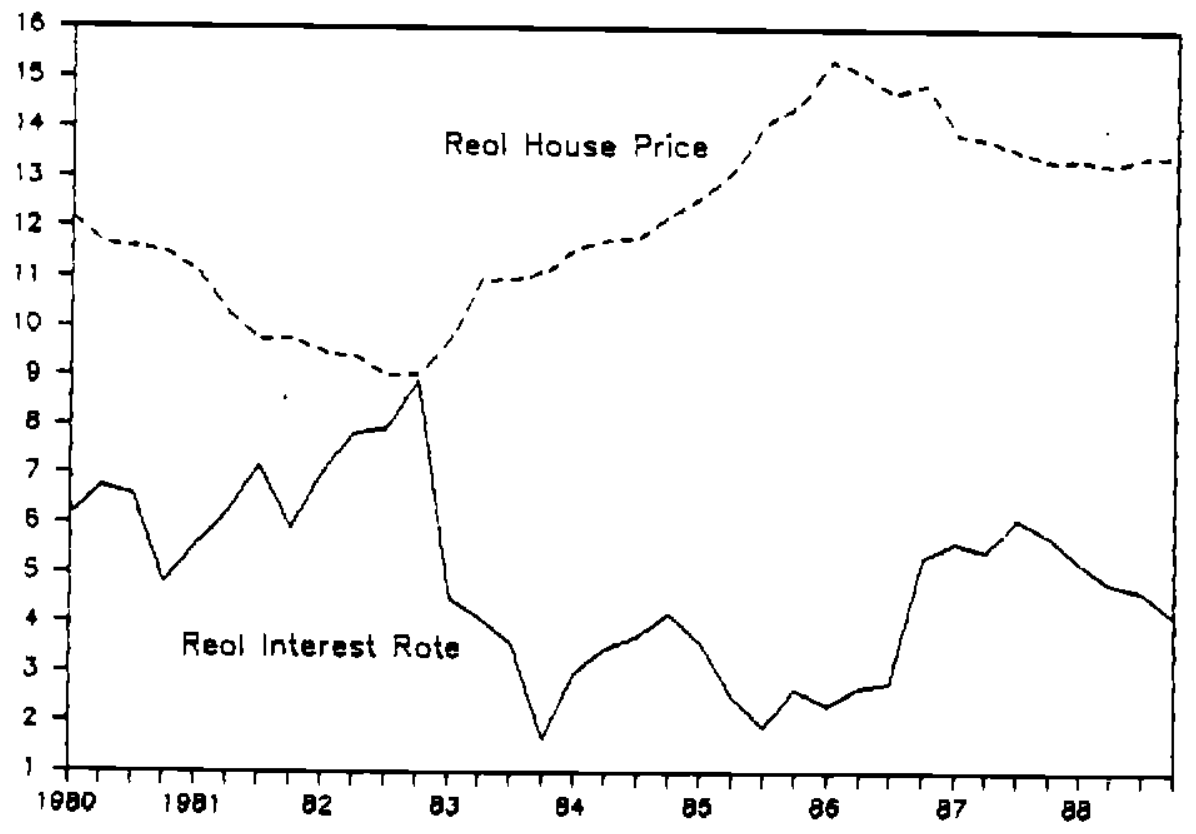

HOUSE PRICE: INDEX, (1972:4 PRICE)/17

SOURCE: Shore Price IMF internationol Finoncial Statistics
House Price By Donmorks Notionalbonk 
increase in the market value of debt: the fall in expected inflation raised the real value of the future interest payments on nominal debt; the fall in the real interest rate decreased the discount rate applying to the real value of those interest payments. This was compounded by the fact that most of the outstanding debt had very long maturities: at the time of the stabilization, Treasury Bills accounted for $15 \%$ of the Danish domestic debt; 85 were fixed-rate bonds with maturities ranging from 3 to 20 years, mostly issued when nominal rates were high. As shown in figure 7, the long maturity "froze" the average cost of debt servicing at relatively high levels, even after its marginal cost -- the yield on new issues -- had fallen by over $10 \%$.

At the same time as asset prices jumped and consumption started to rise, there was a sharp turnaround in "consumer confidence" (figure 6C). 6 The rise in consumer confidence may have resulted partly from the increase in financial and real wealth, and partly from optimism about future income: it is impressive that this wave of consumer optimism occurred at a time when taxes were being dramatically raised, and public services curtailed.

\subsection{Ireland}

The first Irish stabilization of the early 1980s provides instead an example of the textbook case. In 1981 Irish public finances were in a much worse situation than those of Denmark. As a share of GDP, the primary full-employment budget deficit was $8.4 \%$, debt service absorbed $8.3 \%$, and total national debt was $87 \%$.

6 This index is provided by the EC (European Economy, Supplement B). Consumers are asked their views on the "general situation of the economy". A similar picture is obtained by employing an index of their views on their own "financial situation". 
DENMARK: INDEX OF CONSUMERS' CONFIDENCE

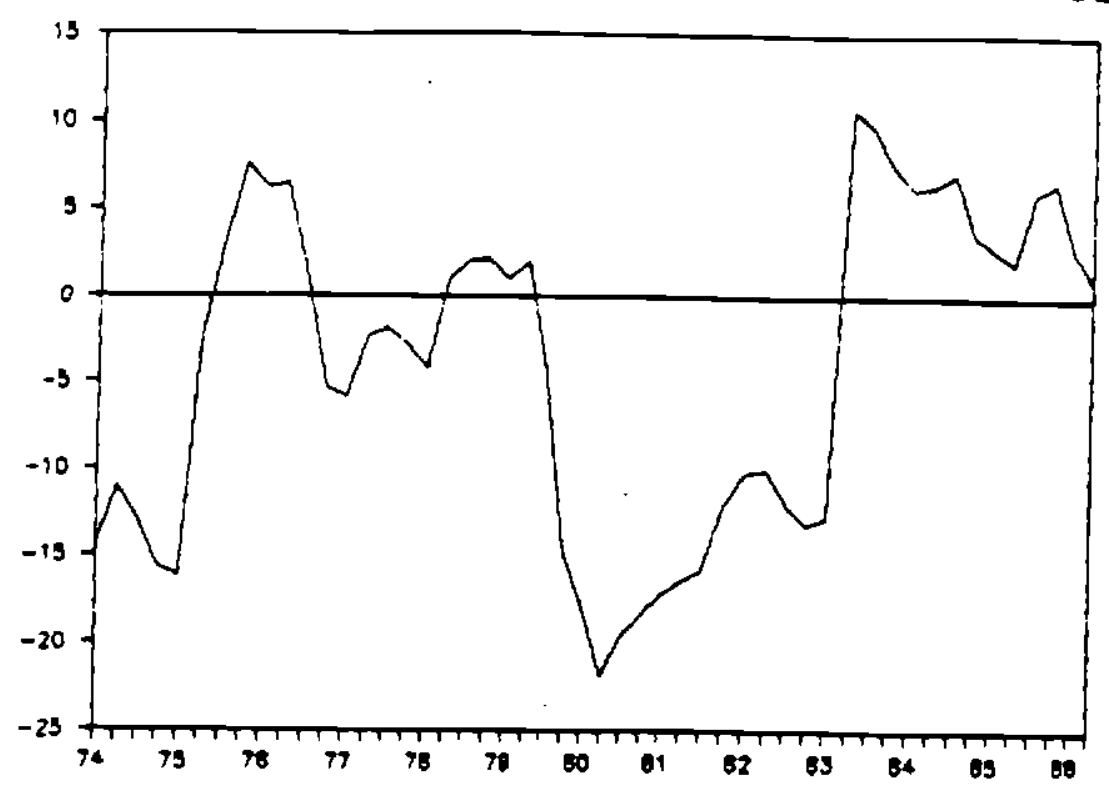

SOURCE: Europeon Economy, Supplement B

FIGURE 6C

DENMARK: MARGINAL AND AVERAGE COST OF PUBLIC DEBT (PERCENTAGE)

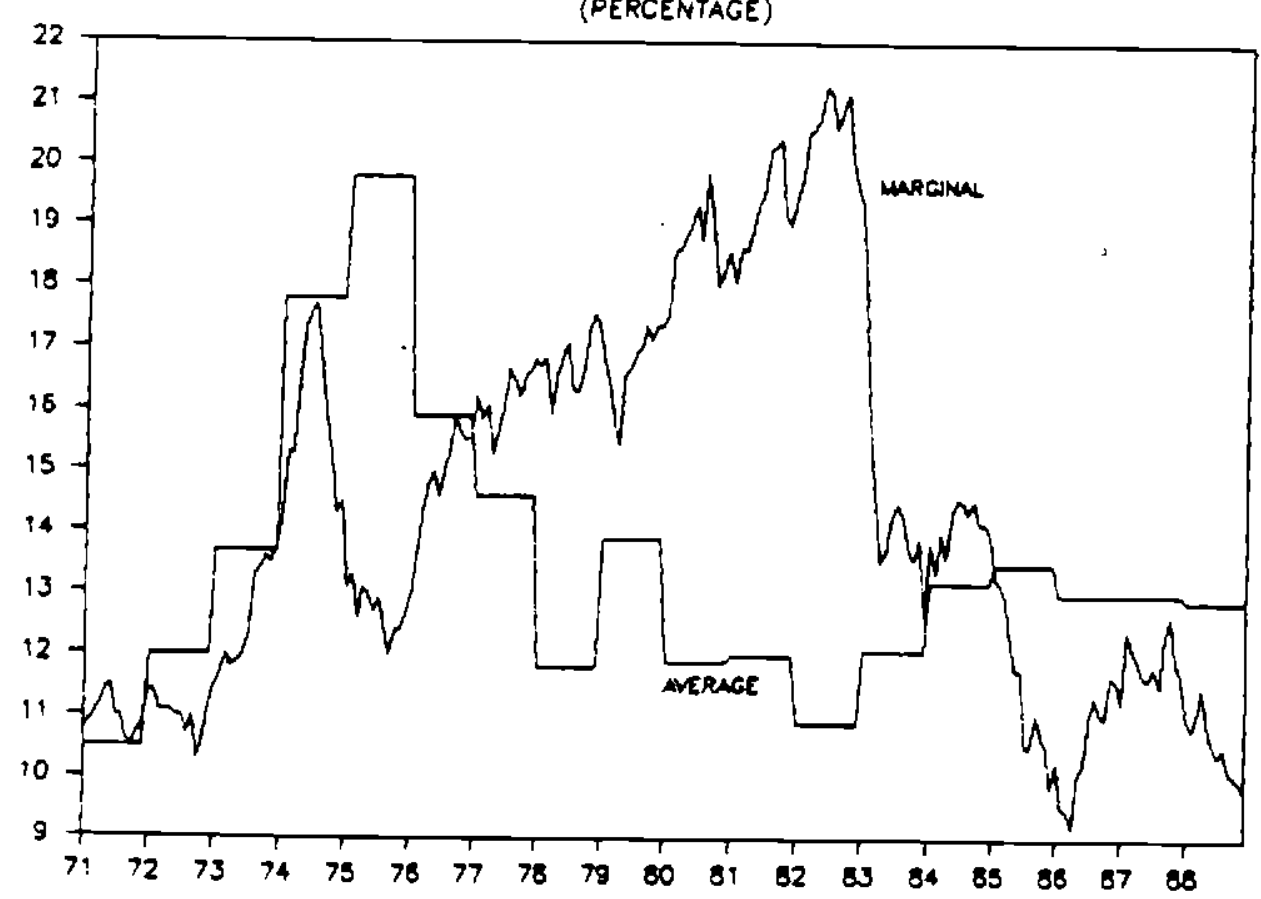

MARGINAL COST: nominor yield on governmem bonos on the morket AVERAGE COST: nominol interest poymants divided by the stock of public oubt on the morket

SCURCE: Doto provided by the Europeon Commission 
The current account deficit exceeded $10 \%$ of GDP. The first serious attempt at fiscal adjustment began in 1982: by 1984 the full-employment primary deficit had been reduced by more than 7 percentage points of GDP, most of it through higher discretionary taxes ( 5.5 percentage points). At the same time, the monetary authorities embarked on a sharp disinflation plan, by pegging the value of the Irish punt within the EMS and thus relative to the German mark. Although this resulted in a drop in both nominal and real interest rates, house and share prices declined, as shown in figures $8 \mathrm{~A}$ and $8 \mathrm{~B}--$ contrary to what was happening in Denmark at about the same time. The deflationary impact on domestic demand was tremendous: real private consumption fell by $7.1 \%$ in 1982 and remained almost flat in the following two years. Business investment decreased dramatically from 1982 to 1984 , despite the fall in real interest rates. The recession was in no way connected with a slowdown in external demand: as shown in table 2 , in the 1982-84 period Irish exports fared exceptionally well on international markets.

In spite of this early failure, the new government elected in February 1987 decided to try again. Elections had brought back to office Charles Haughey, the same prime minister who had attempted the stabilization in 1982, and had been voted out of office after its failure. In contrast with his earlier attempt, that had been carried out in the context of a weak and quarrelsome coalition government, "this time Mr. Haughey flatly refused to enter deals with anyone and launched his minority government on the toughest austerity program the country had witnessed."7 Within two years the full-employment primary deficit was cut

7 Financial Times, Survey on Ireland, September 24, 1987. 
by an additional 7 of GDP. Real growth resumed, and for the first time since the early 1970s the debt-income ratio started to decline.

This time, most of the cut in the primary budget came from lower government consumption and government investment, rather than from the increase in discretionary taxes as in 1982 (see table 2; see also McAleese and McCarthy, 1989). Moreover, what increase in tax revenue did take place was obtained by widening the tax base via a fiscal reform accompanied by a once-and-for-all tax amnesty: in contrast with the experience of the early 1980s, marginal tax rates did not increase, and actually fell slightly. ${ }^{B}$ Another difference with the 1982 experiment stems from the accompanying exchange rate policy: the 1987 stabilization was preceded by a sharp devaluation, while the earlier attempt had occurred at a trough of Irish competitiveness. The behavior of the real exchange rate relative to other EMS currencies is illustrated in figure 9.

However, exchange rate policy eased the stabilization not so much via its direct effect on external demand, but rather via its indirect effect on interest rates and domestic demand. The devaluation stimulated domestic demand by enhancing the credibility of the new parity and thus producing a fall in interest rates: nominal and real rates dropped 5 and 3.4 percentage points respectively in the course of 1987 (see figure 8) -- an indication of "credibility effects in asset markets" (Dornbusch 1989). Export growth, on the contrary, was the same as during the first stabilization (see table 2).

8 The marginal tax rate for a typical married employee with two children had been raised from $39.5 \%$ in 1980 to $43.5 \%$ in 1983: it was reduced to $42.75 \%$ in 1988. Similarly, for a typical single employee the marginal tax rate went from $39.5 \%$ in 1980 to $68.5 \%$ in 1985 , and declined to $65.75 \%$ in 1988. (Source: OECD Economic Surveys, Ireland 1988/1989, table A9, p. 97). 
IRELAND: REAL INTEREST RATE AND REAL SHARE PRICE

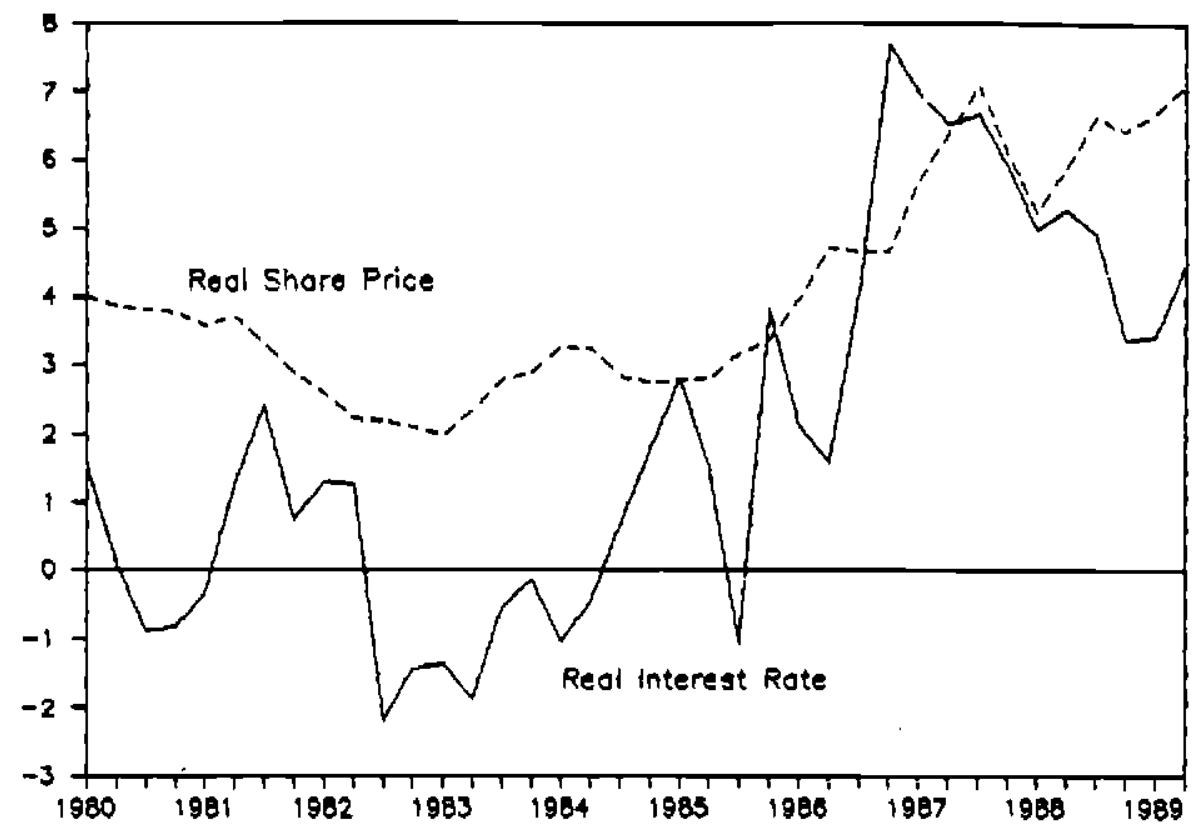

SHARE PRICE: INDEX, 1980:1 = 4

FIGURE 80

IRELANO: REAL INTEREST RATE ANO REAL HOUSE PRICE

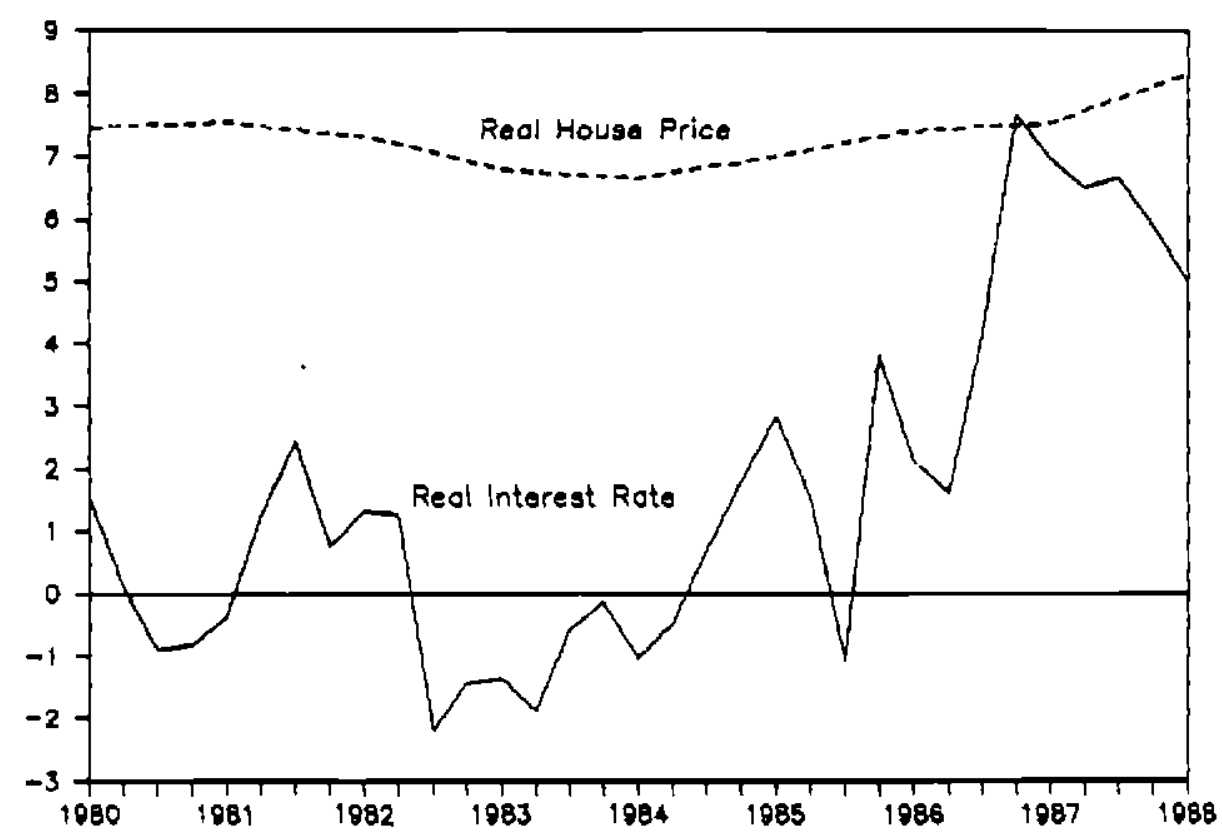

HOUSE PRICE: INDEX, 1980:1 = 7.5

SOURCE: Shore Price IMF, Internotional Finoncial Statistics House Price By Bank of ireland 


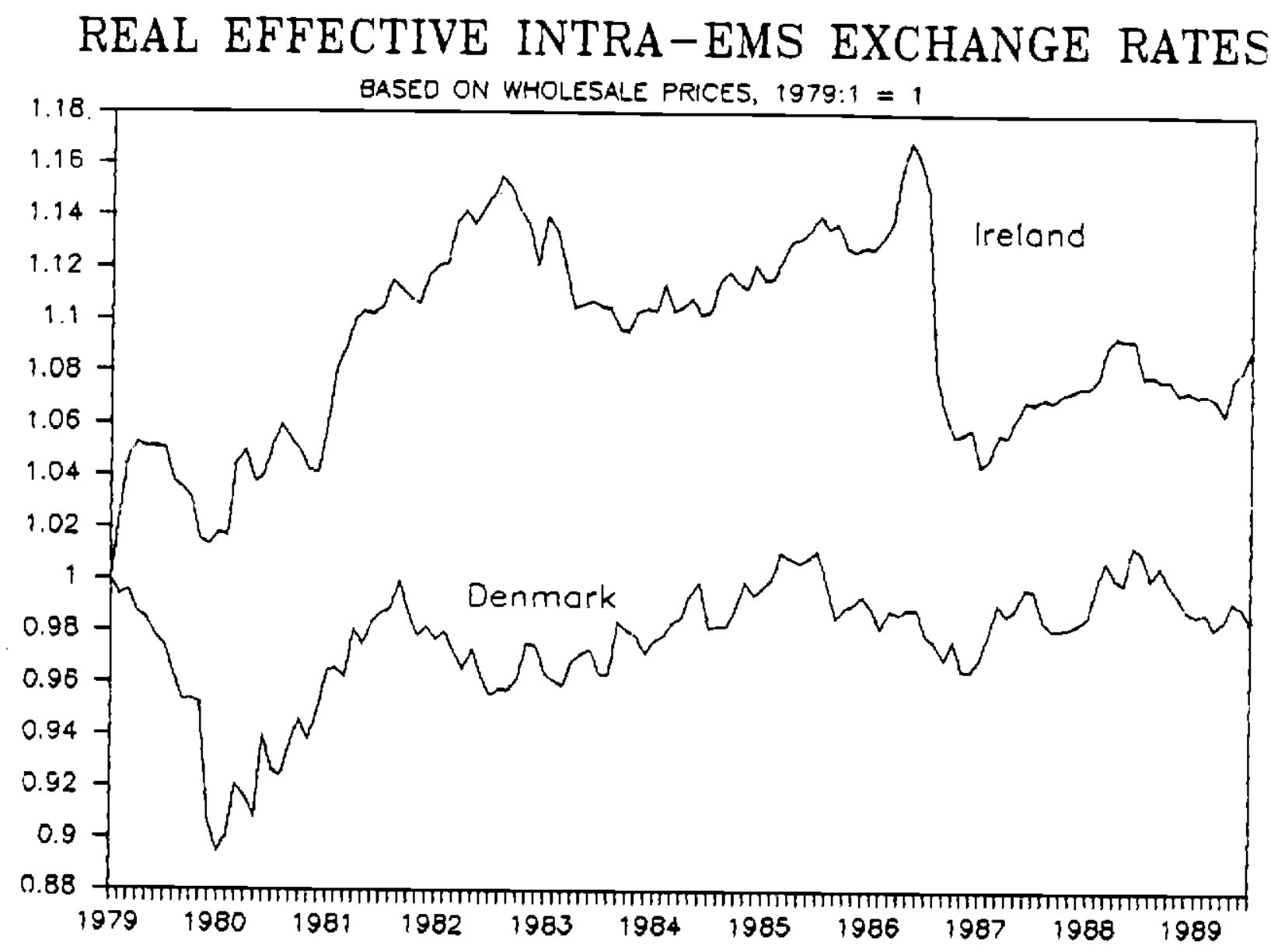

SOURCE: Dato provided by the Bank of Italy

FIGURE 9 


\section{Is there a consuption puszle ?}

In section 2 we have documented the importance of the monetary and exchange rate policies that accompanied the fiscal stabilizations. By pegging the exchange rate to a low-inflation currency, the authorities induced a sharp fall in nominal and real interest rates. This is because, once the exchange rate was credibly fixed, domestic nominal interest rates moved towards the lower level of foreign nominal rates. The convergence of nominal rates occurred faster than the convergence of inflation -- as price stickiness prevented the goods market from adjusting at the same speed as financial markets, where the response to foreign interest rates had been accelerated by the removal of capital controls. The result was that real rates of interest fell along with nominal rates.9

Households were thus subjected to two simultaneous policy shocks: a cut in current disposable income, due to the increase in current taxes, and a wealth effect, due to the unanticipated $f a l l$ in nominal and real interest rates. These changes in disposable income and wealth, and their relative importance, appear as the natural explanations for the observed behavior of consumption. The consumption boom that accompanied the Danish and the second Irish stabilizations could have been produced by an increase in wealth large enough as to overcome

9 This channel, that relies on price stickiness, is quite different from the reason why a fiscal stabilization may be accompanied by a fall in real rates explained in Drazen and Helpman (1989). In their model, the real rate is driven by the anticipated change in the marginal utility of consumption: if the $f$ iscal stabilization occurs through a cut in public spending, the post-stabilization level of private consumption will be higher (because of the implied fall in permanent taxes) and its marginal utility will be lower. In the presence of uncertainty about the exact date of the fiscal stabilization, households will not be able to avoid a jump in their consumption path when the stabilization occurs: accordingly, to forgo consumption prior to the stabilzation they will require a higher real rate. 
any possible contractionary effect stemming from the cut in current disposable income. Conversely, the drop in private consumption that occurred during the first Irish stabilization could be due the absence of a wealth effect, as the fall in interest rates failed to translate into an increase in asset prices.

If this interpretation were to be supported by the data, there would be no reason to resort to the "German view" of fiscal policy to account for our episodes of expansionary contractions. Consumption could be satisfactorily explained by the direct effects of the policy package; there would be no consumption puzzle to be solved by appealing to expectations, namely to the role of current policy shifts as signals of future policies.

\subsection{The direct effects of the stabilization}

The fiscal and monetary policies described so far could in principle have affected consumption through four direct channels: (i) the increase in current taxes, ( $i i)$ the fall in expected inflation, ( $i i i)$ the fall in real interest rates, and (iv) the substitution of private consumption for services no longer supplied by the government.

\subsubsection{Taxes and wealth}

The first three channels are analyzed in the appendix using the eclectic model of Blanchard (1982), that encompasses both a Ricardian world and a non-Ricardian one as special cases. If households have finite horizons, a temporary increase in taxes dampens private consumption: a fiscal consolidation designed to stop the growth of public debt by raising current taxes is contractionary because, even if the present value of taxes remains the same, a larger share of it is paid for by the current generation. A fall in expected inflation can work in 
the opposite direction: if households have finite horizons and public debt consists of long-term fixed-rate nominal bonds, a fall in expected inflation stimulates consumption. This is because the market value of debt goes up, but only part of this capital gain is paid for by the current generation via higher taxes. 10 Finally, a fall in real interest rates raises wealth and consumption whether or not consumers regard public debt as net worth. However, if debt is considered as net worth and consists of long-term bonds, the positive wealth effect on consumption works also through the capital gain on long-term debt that is not fully offset by a corresponding increase in future taxes.

Are these channels sufficient to explain the observed pattern of consumption in Denmark and Ireland? To answer this question, we estimate conventional consumption functions for the two countries and inquire whether, conditioning on the structure of these relations and on the observed path of disposable income and wealth, we can track consumption during the stabilizations of the 1980s.

In the estimation of consumption functions we follow the specification proposed by Hayashi (1982): households' consumption of non-durables and services is a function of its own lagged value, of lagged after-tax labor earnings, of current and lagged wealth, and (to allow for the possibility that some consumers are liquidity-constrained) of current and lagged disposable income. Public debt is introduced as a separate regressor, along with other forms of private wealth,

10 This suggests that debt maturity can have a peculiar effect on the budget in such circumstances. The conventional view of policy-makers is that, when the maturity of public debt is long, rapid disinflation makes fiscal stabilization more difficult, by raising the real burden of debt service. Thus, the longer the maturity of the debt, the larger the required turnaround in the primary deficit. This point, however, overlooks the fact that the wealth effect associated ith the fall in inflation raises private consumption, and thus tax revenue, provicling at least a partial of fset to the increase in debt service. 
to avoid imposing a restriction on the degree of tax discounting. The appendix shows the derivation of this consumption function, and the need to estimate it by non-linear instrumental variables to account for the endogeity of wealth and disposable income while imposing the non-linear restrictions implied by the model.

The results reported in table 3 show that the model's restrictions are always accepted at conventional significance levels. As far as Denmark is concerned, the magnitude of $\theta$ and the precision of its estimate indicate that the path of wealth (net of public debt), $A(t)$, significantly affects that of private consumption. For Ireland, instead, net wealth is significant only when disposable income is onitted from the regressors.

The coefficient on public debt, $\beta$, is instead very imprecisely estimated for both countries. This casts doubt on the proposition that capital gains on public debt have driven consumption during the 1980s.' 1 A warning however is in order: here public debt should be measured at market value, particularly since we know that there have been large capital gains on debt. Such a series is available only for Denmark. For Ireland we have no choice but to use data on public debt at book value, so that our estimates for this country should be taken with some skepticism. Nevertheless, there is another piece of evidence suggesting that in Ireland capital gains on public debt may have no effect on consumption. We know that the average maturity of Irish public debt is long (see Giavazi and Pagano, 1989), and that both stabilizations were accompanied by a sharp fall in nominal and real interest rates: the market value of Irish

11 Our results for Ireland appear to confirm the finding by Moore (1987) that public debt has no role in the Irish consumption function. 
Table 3

Consumption function estimates a, b

Regression: $\quad C(t)=(1+\delta) C(t-1)+\theta\{A(t)-(1+\delta)[A(t-1)+w(t-1)]\}$

$+B[D(t)-(1+\delta) D(t-1)]+\mu[Y(t)-(1+\delta) Y(t-1)]$

\begin{tabular}{lllll}
\hline & $\theta$ & $\boldsymbol{N}$ & $\mu$ & $\begin{array}{l}\text { Constraints } \\
\text { not rejected } \\
\text { below:c }\end{array}$ \\
\hline
\end{tabular}

Denmark (1971-87), yearly data:

\begin{tabular}{|c|c|c|c|c|c|c|}
\hline 1. & $\begin{array}{l}.050 \\
(1.60)\end{array}$ & $\begin{array}{l}.025 \\
(1.58)\end{array}$ & $\begin{array}{l}.031 \\
(.86)\end{array}$ & $\begin{array}{l}.003 \\
(.09)\end{array}$ & $75 \%$ & .845 \\
\hline 2. & $\begin{array}{l}.050 \\
(1.74)\end{array}$ & $\begin{array}{l}.025 \\
(1.64)\end{array}$ & $\begin{array}{l}.032 \\
(.90)\end{array}$ & & $75 \%$ & .856 \\
\hline 3. & $\begin{array}{c}.053 \\
(1.86)\end{array}$ & $\begin{array}{c}.026 \\
(1.82)\end{array}$ & & $\begin{array}{l}.005 \\
(.06)\end{array}$ & $75 \%$ & .856 \\
\hline 4. & $\begin{array}{l}.063 \\
(2.27)\end{array}$ & $\begin{array}{c}.032 \\
(2.28)\end{array}$ & & & $50 \%$ & .869 \\
\hline \multicolumn{7}{|c|}{ Ireland (1961-87), vearly data: } \\
\hline 5. & $\begin{array}{l}.084 \\
(1.53)\end{array}$ & $\begin{array}{l}.035 \\
(1.49)\end{array}$ & $\begin{array}{l}.792 \\
(.33)\end{array}$ & $\begin{array}{c}.191 \\
(1.42)\end{array}$ & $25 \%$ & .974 \\
\hline 6. & $\begin{array}{c}.108 \\
(2.20)\end{array}$ & $\begin{array}{l}.056 \\
(2.94)\end{array}$ & $\begin{array}{l}1.44 \\
(.82)\end{array}$ & & $50 \%$ & .966 \\
\hline 7. & $\begin{array}{c}.081 \\
(1.49)\end{array}$ & $\begin{array}{l}.033 \\
(1.39)\end{array}$ & & $\left(\begin{array}{l}.230 \\
(1.80)\end{array}\right.$ & $50 \%$ & .976 \\
\hline 8. & $\begin{array}{c}.110 \\
(2.38)\end{array}$ & $\begin{array}{c}.062 \\
(3.25)\end{array}$ & & & $75 \%$ & .966 \\
\hline
\end{tabular}

Footnotes on page 
public debt must thus have jumped in both stabilizations. But the two fiscal corrections had opposite effects on consumption. ${ }^{12}$

The estimates of the coefficient $\mu$ show that, while in Ireland anticipated changes in current disposable income have a substantial effect on consumption, in Denmark consumption and current disposable income seem completely decoupled. This difference between the two countries is consistent with the dissimilar response of consumption during the Danish and Irish stabilizations: in Denmark wealth effects sheltered consumption from the fall in current disposable income; in Ireland, instead, during the first stabilization consumption took all the brunt of higher taxes, while the consumption boom of the late 1980s was helped by the rise in disposable income (see table 2).

A significant value for the parameter $\mu$ is evidence of a departure from the permanent income hypothesis that can be interpreted as a symptom of liquidity constraints or of consumers' myopia. Additional evidence on this point can be obtained by estimating Euler equations for aggregate consumption of nondurables. As shown by Hall (1978) and Hayashi (1982), under suitable assumptions, the proportion of income accruing to liquidity-constrained households can be measured by the excess sensitivity parameter in the Euler equation. Estimates of this equation are reported in table 4 . To correct for

12 The only factor that could restore some credibility to the hypothesis that public debt affects consumption is the fact that Irish households hold directlv only a negligible fraction of the outstanding debt: most of it is held in the portfolios of pensions funds, insurance companies and other institutions, and households cannot easily liquidate their position in pension funds or borrow against their equity in insurance companies. These institutional constraints can dampen the size of wealth effects on consumption: the financial liberalization that has occurred in Ireland in the late 1980 s could then go somewhat towards reconciling the different outcomes that the capital gain on public debt may have had in the two stabilizations. 
the endogeneity of current disposable income, the equations are estimated by non-linear instrumental variables (NLIV). Since the constraint $\alpha=1$ in most cases is not rejected, we also re-estimate the equation by regressing the first differences of consumption on those of disposable income. In addition, we report the results obtained by using full information maximum likelihood (FIML) to estimate the consumption equation jointly with a predictive equation for disposable income, and imposing the relevant cross-equations restrictions. The results confirm that consumption responds strongly to anticipated changes in current disposable income in Ireland, but not in Denmark.13

It is natural to ask which structural differences between the two countries lie behind these results. The answer may rest in the very different functioning of credit markets in the two countries. In Denmark, lending to households plays a central role in financial intermediation, and there is no rationing in the market for credit to households. A survey conducted on behalf of the Central Bank since 1981 reveals that only $2 \%$ of households postpone purchases of consumer durables because they have received or believe they would receive a loan refusal (Kjaer 1987), ${ }^{14}$ In Ireland, instead, credit to households has traditionally been less plentiful. Only in the late 1980s this has started to change, as the mortgage market, formerly the preserve of building societies, has been opened to competition by commercial banks.

A reflection of this institutional difference between the two countries can

13 The only regression for Ireland which does not display excess sensitivity is that estimated with FIML without imposing the constraint $\alpha=1$. In this case, however, the other constraints on the model are rejected by the data at the conventional $5 \%$ significance level.

1't These data are based on the "omnibus survey", conducted by Danmarks Statistik on a sample of 1,400 wage and salary-earning households, three times a year. 
Table 4

Excess sensitivity of consumption in Denmark and Ireland a

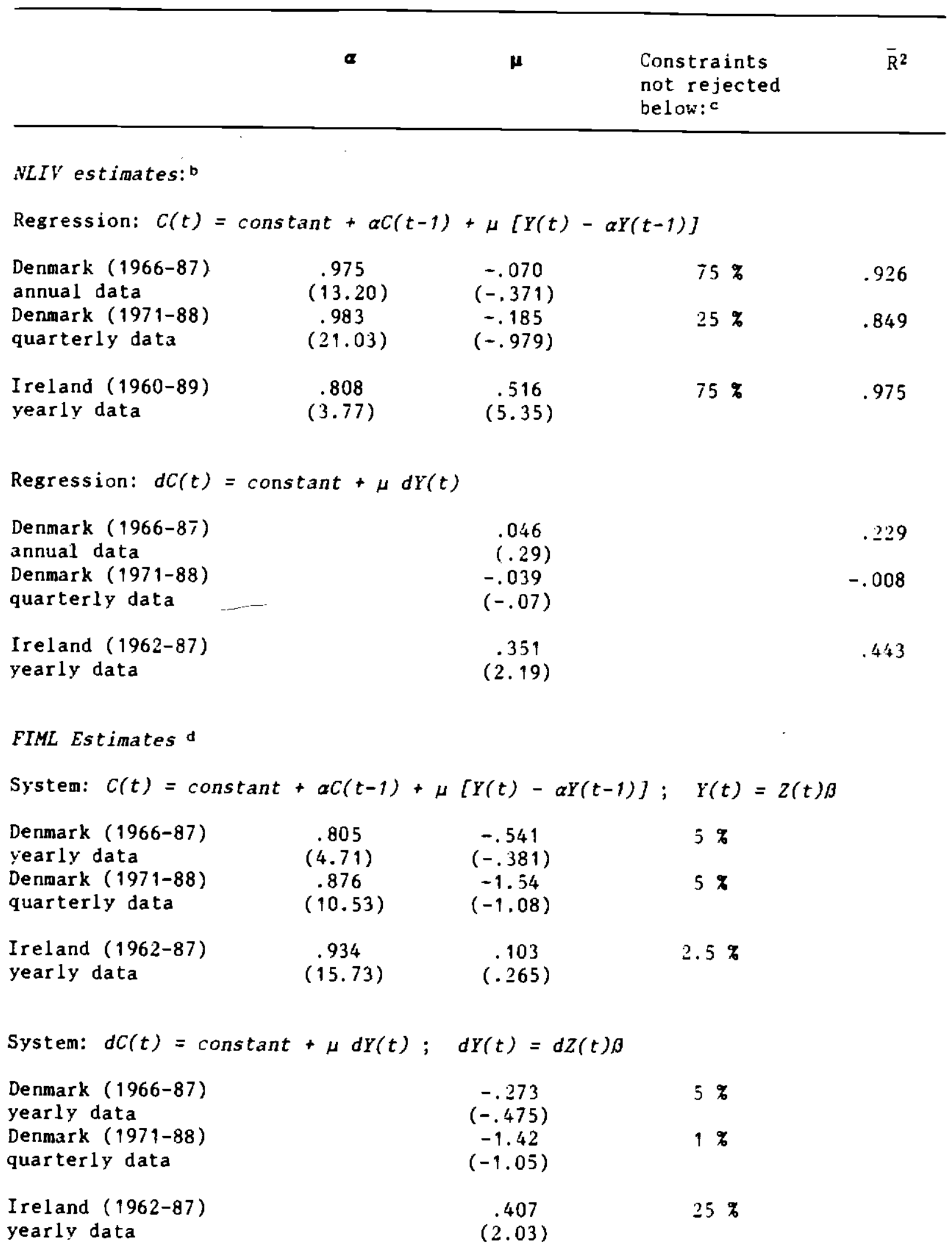


Footnotes to Table 3:

d $C$ is consumption of non-durables. For Denmark it is defined as total consumption minus rent, fuel and power, furniture and household equipment and personal transport equipment (source: OECD NIA). For Ireland it is total consumption minus clothing and footwear, durable household goods, and transport equipment (source: Central Bank of Ireland, as in Moore 1987). $Y$ is disposable income of the private sector for Denmark (source: Central Bank of Denmark) and of the household sector for Ireland (source: Central Bank of Ireland). For both countries, $A$ is beginning-of-period wealth, net of public debt $D$, of social security wealth, and of domestic assets held by foreigners; it includes houses at market prices and business capital valued at replacement cost. For Denmark, wealth is constructed by subtracting the entire stock of domestically held debt $D$ from private sector weal th (we subtract also public debt held by banks to net out the portion of deposits which has public debt as counterpart on the balance sheet of banks). The variable $w$ is labor income, after-tax for Denmark and before-tax for Ireland (source: Central Bank of Denmark, and OECD NIA for Ireland). All variables are in real per capita terms (the deflator used is that for non-durables consumption).

- The estimation method is NLIV, and the estimates reported in the table are obtained by imposing the non-linear constraint on the coefficients of the equation. The instruments are a constant, a time trend and one lag of net wealth, disposable income, labor after-tax income, government consumption, government investment, real money, investment, terms of trade (defined as the ratio of import prices to the deflator of consumption of non-durables). Source: OECD NIA.

$c$ The test refers to the non-linear constraint on the coefficients of the equation; the test statistic is the quasi-likelihood ratio of Gallant and Jorgenson computed by TSP. The percentage value shown in the table is the significance level below which the constraints are accepted: a higher

significance level is a tighter criterion on the null hypothesis, since it corresponds to a lower probability of a type II error.

Footnotes to table 4 :

a Variables are defined as in table 3. In the quarterly regressions for Denmark, consumption of non-durables is defined as total consumption minus clothing and footwear, housing equipment and personal transport equipment (source: Central Bank of Denmark).

- In the regressions on yearly data, the instruments are the first lag of disposable income, government consumption, government investment, net exports and a time trend. In the equations that employ differences of consumption and investment ( $d C$ and $d Y$ ), the instruments are the same variables in differenced form. In the regressions on quarterly data, the instruments are four lags of disposable income and of consumption.

c In the NLIV estimates, the test refers to the non-linear constraint on the coefficients of the equation for $C$; the test statistic is the quasi-likelihood ratio of Gallant and Jorgenson computed by TSP. In the FIML estimates, we test jointly this non-linear constraint and the cross-equation constraints between the equations for $C$ and $Y$; in this case we use a likelihood ratio test. For the interpretation of these values, see table 3 . In both cases, the results reported in the paper refer to the constrained estimates.

d The set of regressors $Z$ in the predictive equation for $Y$ includes the same variables used as instruments in the NLIV regressions. 
be found in the different size of the market for consumer loans documented in table 5: in Denmark total lending to consumers (the sum of consumer credit and housing mortgages) is about 3 times as large as in Ireland, as a percentage of total consumption. To put these numbers in perspective, consider that in the $t S$ in 1984 the ratio of consumer credit to consumption was $24 \%$ and the corresponding figure for housing mortgages was $57 \%$-- a total of $81 \%$ to be compared with $150 \%$ in Denmark and $43 \%$ in Ireland.15 Table 5 also documents the tremendous $r$ ise in consumer lending during the Danish stabilization. The second Irish stabilization was also accompanied by a rise in consumer lending, though to a much smaller degree.

\subsubsection{Substitution between public and private goods}

The analysis conducted so far implicitly assumes that public consumption is a pure waste of resources, vielding no utility to consumers -- an assumption increasingly questioned in recent research (see e.g. Aschauer 1985). If consumers value the public provision of services such as schools, health care and the like, they will increase private spending on these items when they are no longer provided by the government. Thus, substitution of private for public consumption is an additional direct channel between fiscal policy and private expenditure. To the extent that there is such substituion, the apparent increase in private consumption reflects simply measurement error: if one could

15 The relationship between the size of the market for consumer lending and the excess sensitivity of consumption that we find here parallels the results in Jappelli and Pagano (1989) for other 7 OECD countries. Other evidence pointing to the importance of the market for consumer lending in explaining consumption behavior is reported by Muellbauer and Murphy (1989), that analyze the tK credit market liberalization of the 1980s, and by Bayoumi and Koujianou (1989), who look at evidence from the US, Japan, Canada, the UK, France and Sweden. 
Table 5

Consumers' liabilities as a percentage of consumers' spending

\section{Housing mortgages}

Derımark

$1978-82$

1984

1986

1988
$94 \%$

$120 \%$

$153 \%$

$184 \%$
Ireland

$35 \%$

$37 \%$

$42 \%$
Consumers' credit

Denmark Ireland

$29 *$

$30 \%$

$8 \%$

$40 \%$

$9 \%$

$37 \%$

$11 \%$

Sources: Central Bank of Denmark, Monetarv Review, Tables 22 and 23 ; Central Bank of Ireland, Quarterly Bulletin, Table C6; and Irish Building Societies; data for the stock of housing mortages in Denmark have been provided directly by the Central Bank of Denmark. 
measure true consumption, rather than consumer spending on private sector output, one would find that it has not increased.

To provide a rough assessment of the relevance of this measurement error, we compare the increase in private spending with the reduction of public spending on the items for which substitution is most likely. Table 6 shows that in 1983-84 the Danish government slashed spending on health care, education, entertainment and provision of public transportation proportionately more than other spending. On their side, Danish households increased private spending on these services by more than their total consumption expenditure: this is particularly evident in the case of education, entertainment and cultural services. While this constitutes evidence in favor of the substitution hypothesis, the empirical magnitude of this factor seems quite modest, relatively to the total surge in consumption to be explained: the contribution of spending on these classes of services to the total increase in consumption in those two years is only $14.9 \%$.

\subsection{The consumption puzzle and the role of expectations about future policy} Once we control for changes in disposable income and wealth, is there still a large fraction of the observed changes in consumption that remains to be explained? And do the forecast errors coincide with the years of the fiscal contractions? For Denmark, we have used the consumption function reported in line 1 of table 3 to construct out-of-sample dynamic forecast errors for the years 1984-87. The equation significantly underpredicts consumption from 1985 onwards : 


\section{Table 6}

Denmark: changes in public and private consumption, selected classes a (at constant prices, percentage changes per year, 1983-84)

\begin{tabular}{|c|c|c|c|}
\hline \multicolumn{2}{|c|}{ Changes in government consumption } & \multicolumn{2}{|c|}{ Changes in private consumption } \\
\hline Total & -0.2 & 3.0 & Total \\
\hline Classes: & & & Classes: \\
\hline Medical personal services & -0.9 & 2.5 & Physicians and dentists \\
\hline Hospitals & 0.3 & 5.8 & Hospital care \\
\hline Education & -0.4 & 3.4 & Education \\
\hline $\begin{array}{l}\text { Entertainment and } \\
\text { cultural services }\end{array}$ & -2.5 & 4.8 & $\begin{array}{l}\text { Entertainment and } \\
\text { cultural services }\end{array}$ \\
\hline $\begin{array}{l}\text { Transportation, net of } \\
\text { spending on roads and } \\
\text { waterways }\end{array}$ & -6.4 & 3.1 & $\begin{array}{l}\text { Transportation, net of } \\
\text { spending on personal } \\
\text { transport equipment }\end{array}$ \\
\hline All these classes & -0.9 & 3.4 & All these classes \\
\hline , & & 14.9 & $\begin{array}{l}\text { Contribution to change } \\
\text { in private consumption }\end{array}$ \\
\hline
\end{tabular}

a Source: Danish Statistical Yearbook. Public spending in each class is deflated by the deflator of private consumption in the corresponding class. 
Dynamic forecast errors as of 1983 (percent of the forecast, yearly data):

$\begin{array}{rrrr}1984 & 1985 & 1986 & 1987 \\ -0.03 \% & 1.90 \% & 3.36 \% & 3.53 \%\end{array}$

To appreciate the magnitude of these numbers, consider for example that the error of $3.36 \%$ in 1986 implies a predicted growth rate of real per capita consumption of $1.8 \%$, while the actual growth rate in that year was $4.1 \%$. Using quarterly data we can repeat this exercise with an added gain in accuracy: owing to the larger number of observations, we can estimate the same regression with data up to $1983: 1$, so that the structure of the model reflects only information available at the time of the forecast. ${ }^{16}$ For comparability with the forecast errors obtained on yearly data, we report averages of the quarterly errors:

Dynamic forecast errors as of 1983:1 (percent of the forecast, quarterly data):

$\begin{array}{llllll}1983 & 1984 & 1985 & 1986 & 1987 & 1988 \\ 0.04 \times & 0.90 \% & 3.00 \% & 5.80 \% & 6.10 \% & 3.20 \%\end{array}$

For Ireland, we have replicated this procedure only on yearly data. We have computed dynamic forecasts from a regression for total consumption, rather than

16 The equation used to produce the forecast uses the same variables and instruments as that reported in line 1 of table 3 , but does not impose the nonlinear restriction across parameters (using quarterly data, these restrictions are rejected at the $10 \%$ significance level). 
for non-durable consumption (data for the latter were not available for 1988, the first year of the successful stabilization). The regressors are the same as in 1 ine 5 of table 3.17 In 1988 the growth rate of real per capita consumption was $2.65 \%$, while that forecasted by our regression is $0.6 \%$.

Since these forecasts are computed by conditioning on the actual realizations of the exogenous variables, including wealth, these errors cannot be attributed to the increase in wealth due to the fall in interest rates and the jump in asset prices documented in figures 6 and 8 . There is indeed a consumption puzzle.

Can the German view of fiscal policy help to resolve it? As discussed above, this view turns on the idea that fiscal consolidation can be read by the private sector as a signal that the share of government consumption in GDP is going to be reduced permanently, so that also taxes will be permanently lower. This would lead households to revise upwards their estimate of their human capital (the discounted value of after-tax labor income), and to raise current and planned consumption. In the appendix we show that the effect of permanent spending cuts on private consumption is positive whether consumers have infinite horizons or not (although the quantitative significance of the effect depends on the length of their horizon, among other things).

For this view to be consistent with the data, it must be true that households perceived the spending cuts as permanent, and the concomitant tax increases as temporary. On the first point, we already know from figure 3 that our proxy for

17 Also in this case, the forecasting equation was estimated without imposing the restrictions maintained in table 3. 
permanent government consumption has declined after the inception of the stabilization plans. On the other hand, actual taxes have started to come down in Denmark after 1986 and in Ireland after 1987, although they are still well above the level of the 1970 s (see figure 10 that shows cyclically-corrected taxes, net of transfers and subsidies).18

A more refined test of the expectations view turns on the following point. Under rational expectations, the error term of the consumption function reflects innovations in permanent disposable income. Now, suppose that announcements of spending cuts are indeed read as "good news" about future disposable income, i.e. as a signal that the government is about to reduce taxes accordingly further in the future. Then one should find a negative correlation between consumption surprises and surprises in permanent spending by the government (see appendix). We ran a simple OLS regression between the in-sample residuals of our consumption function for Denmark ( 1 ine 1, table 3) and changes in government consumption, as proxy for the surprises in permanent public spending. The relationship is negative, but it is significant (at the $10 \%$ level) only when the regressor is the lagged change in public spending, not its current value:

$$
\begin{aligned}
& \text { consumption residual }=\text { constant }-\begin{array}{ll}
0.197 E-3 & \text { lagged change in } \\
\text { government consumption }
\end{array} \\
& \overline{\mathrm{R}}^{2}=0.11 \quad \mathrm{DW}=2.36
\end{aligned}
$$

This lagged response may reflect the institutional delay in the release of revised figures for government spending, so that it is reasonable to suppose

18 Figure 10 displays cyclically-adjusted taxes, net of interest and subsidies, as a percentage of potential output. This cyclical correction should eliminate 


\section{CYCLICALLY CORRECTED NET TAXES}

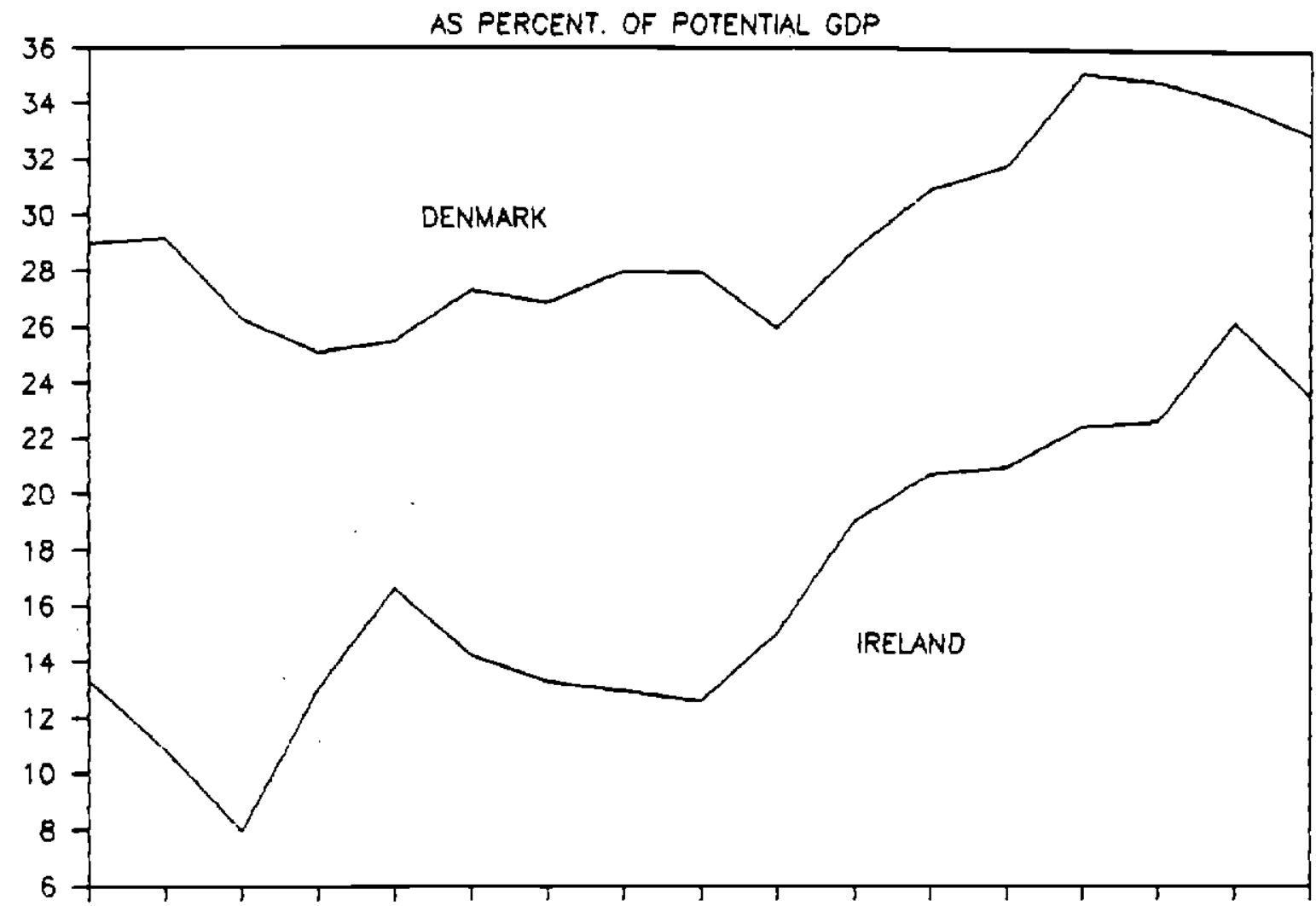

19731974197519761977197819791980198119821983198419851986198719881989

SOURCE: OECO, Notional income Accounts and European Commission

FIGURE 10 
that people update their estimate of permanent spending with a lag.

In Ireland, instead, no significant correlation is found between consumption residuals and changes in government spending. This may perhaps be due to the presence of liquidity constraints, that we have documented in the previous section: the positive impact on consumption of a fall in permanent taxes can be

dampened is consumers are unable to borrow freely against their human capital or their equity.

\subsection{Summing up}

It may be useful at this point to summarize our findings about the consumption puzzle. For Denmark, there is considerable evidence in favor of the view that the consumption boom of 1984-86 cannot be fully explained by the fall in interest rates and the implied wealth effects, and that the unexplained component of the boom is related to cuts in public spending. This is consistent with the view that cuts in current government consumption were seen as a signal of lower taxes further in the future.

For Ireland, instead, the main $f$ inding is that consumption is driven primarily by disposable income -- probably a reflection of the importance of liquidity constraints in the Irish economy. This may explain the contractionary effects of the first Irish stabilization, when the reduction in disposable income translated directly into a corresponding drop in consumption. What then explains the consumption boom that accompanied the second Irish stabilization? Probably a combination of factors: first, the axe of the new government fell

most the endogeneity of this variable. 
more heavily on public spending than on households' disposable income, unlike a few years before, and the increase in tax revenue was obtained while reducing marginal tax rates; second, the liberalization of the Irish credit markets in the late 1980s may have increased the ability of households to borrow in anticipation of higher future incomes. It is tempting to relate the large forecast error of the Irish consumption function in 1988 with these two factars, and to conclude that the "German view" may have something to say also for the second Irish stabilization.

\section{Real interest rates and investment}

In section 3 we have argued that part of the expansionary effects associated with the fiscal stabilization in our two "test countries" may actually stem from the fall in real interest rates associated with the concomitant monetary and exchange rate policies. Obviously, a fall in the long-term real rate of interest stimulates investment. Nevertheless, this appears not to be enough to explain the investment boom in Denmark in 1985-6: when we estimate a simple reduced form equation for business investment, that includes one lag of investment and of the real cost of capital, and two lags of real GDP, we find that its dynamic forecasts significantly underpredict investment in these years: 19

19 Investment, I, is defined as gross business investment; $Y$ is real GDP (Source: OECD, National Income Accounts). The user cost of capital is defined as $U C=[(1+i) *(1-t)] /\left(1-\pi^{e}\right)$ where $i$ is the Danish bank loan rate, $t$ is the corporation tax rate, and $\pi^{e}$ is expected inflation over a 5-year horizon, built using the same methodology described in footnote 2 . The regression is estimated on yearly data from 1971 to 1988 , and has a corrected $R^{2}$ of .732 , and a Durbin Watson value of 2.33. Very similar results were obtained using data from 1961, but omitting the user cost of capital, that is not available before 1971 . 


$$
I(t)=\text { constant }+.41 I(t-1)+.37 Y(t-1)-.27 Y(t-2)-.10 U C(t-1)
$$

$$
(1.85)
$$

Forecast errors as of 1983 (percent. of the forecast):
$\begin{array}{llccc}1984 & 1985 & 1986 & 1987 & 1988 \\ -0.83 \% & 3.2 \% & 10.0 \% & -1.1 \% & 3.5 \%\end{array}$

This evidence is consistent with two alternative explanations. As in the case of consumption, investment decisions may reflect an increase in profitability associated with the anticipated cut in future taxes. An alternative explanation is suggested by the observation that the decision to peg the exchange rate and to remove capital controls was accompanied by massive capital inflows: foreign borrowing by private enterprises, in 1984 and 1985, accounted for $42 \%$ and $51 \%$ respectively of gross business investment expenditure. ${ }^{20}$ The reaosn is probably that although, as we know, nominal interest rates fell considerably at the announcement of the stabilization, they remained higher than German rates. In the presence of a credibly fixed exchange rate, borrowing abroad became a very convenient proposition: domestic firms suddenly faced lower real rates -- equal to the German nominal rate minus the domestic inflation rate. In this context, the removal of controls on capital inflows by the Danish authorities was equivalent to a positive demand shock.

20 OECD, Economic Survey of Denmark, 1987, p. 52. 


\section{What have we learned?}

We started this paper by asking whether the European exercise in fiscal rectitude in the 1980 s sheds any light on two contending views about the effects of a fiscal contraction: the Keynesian view, that focuses on its direct effects on aggregate demand, and the "expectations" view -- also known in Europe as the "German view" -- that stresses the role of current changes in taxes or in government spending as signals of possible future changes. We have learned that there are cases in which the German view has a serious claim to empirical relevance. The Danish experience shows that cuts in government spending can be associated with increases in consumption even after controlling for wealth and income, and even in the presence of a substantial increase in current taxes. The Irish case, however, highlights the potential importance of liquidity constraints for the operation of this mechanism. When current disposable income effectively constrains consumption, Keynesian textbook propositions seem to recover their predictive power, as witnessed by the $7 \%$ drop in real consumption in 1982 during the first Irish stabilization.

We have also found that part of the expansionary effects of the fiscal contractions analyzed here must be attributed to the concomitant monetary disinflation, that in these countries operated via the switch to fixed exchange rates with a low-inflation currency (the German mark), and the liberalization of capital flows. This produced a sharp fall of nominal interest rates: in the presence of inflation inertia, the latter translated into a corresponding drop of real rates and a rise in aggregate demand. This expansionary effect, however, crucially hinged upon the credibility of the fixed parity chosen by the 
monetary authorities: it is remarkable that in both our cases of "expansionary contractions" the shift in fiscal and exchange rate policy was preceded by a sizable devaluation.

\section{REFERENCES}

Ahmed, S. (1987), "Government spending, the balance of trade and the terms of trade in British history,", Journal of Monetary Economics, Vol. 20, No. 2, September, 195-220.

Andersen T.M. and 0 . Risager (1987), "The Role of Credibility for the Effects of a Change in the Exchange Rate Pol icy", Seminar paper No. 377, Stockholm University, Institute for International economic Studies.

Aschauer, D. A. (1985), "Fiscal Policy and Aggregate Demand," American Economic Review, Vol. 75, No. 1, 117-127.

Barro, R. (1979), "On the Determination of Public Debt," Journal of Political Economy, Vol. 87, No. 5, 940-971.

Barro, R. (1981), "Output Effects of Government Purchases," Journal of Political Economy, Vol. 89, No. 6, 1086-1121.

Bayoumi, T. and P. Koujianou (1989), "The Effects of Financial Deregulation on Consumption," IMF Working Paper $89 / 88$, October.

Blanchard, 0. J. (1985), "Debt, Deficits and Finite Horizons," Journal of Political Economy, Vol. 93, No. 2, 223-247.

Christensen, A. M. (1988), "Indkomst, Formue og Privatforbrug," mimeo., Central Bank of Denmark.

Christensen, M. (1986), "Policy Credibility and the Lucas Critique: Some New Tests with an Application to Denmark", University of Aarhus, Institute of Economics, Memo 1987-8.

Danish Ministry of Finance (1983), "Government Finances in Denmark," Department of the Budget, Smátryk, nr. 32, January. 
Dornbusch, R. (1989), "Credibility, Debt and Unemployment: Ireland's Failed Stabilization," Economic Policy, 8, April, 173-210.

Drazen, A. and E. Helpman (1989), "Inflationary Consequences of Anticipated Macroeconomic Policies," The Review of Economic Studies, Vol. 57 (1), No. $189,147-164$.

Feldstein, M. (1982), "Government Deficits and Aggregate Demand," Journal of Monetary Economics, Vol. .9, No. 1, January, 1-20.

Fels, G. and H. P. Froelich (1986), "Germany and the World Economy: a German View," Economic Policy, 4, April, 178-195.

Giavazzi, F. and M. Pagano (1989), "Confidence Crises and Public Debt Management", NBER Working Paper No. 2926.

Hall, R. E. (1978), "Stochastic Implications of the Life-Cycle Permanent Income Hypothesis," Journal of Political Economy, Vol. 86, No. 6, December, 971-987.

Hayashi, F. (1982), "The Permanent Income Hypothesis: Estimation and Testing by Instrumental Variables," Journal of Political Economy, Vol. 90, No. 5, October, 895-916.

Hellwig, M. and M. J. M. Neumann (1987), "Economic Policy in Germany: Was There a Turnaround ?," Economic Policy, 5, October, 105-140.

Jappelli, T. and M. Pagano (1989), "Consumption and capital market imperfections: an international comparison," American Economic Review, Vol. 79, December.

Kjaer, J. H. (1987), "Consumer Lending," Monetary Review, Danmarks Nationalbank.

McAleese, D. and F. D. McCarthy (1989), "Adjustment and External Shocks in Ireland," World Bank, International Economics Dpt., WPS 262, August.

Moore, J. M. (1987), "The Irish Consumption Function and Ricardian Equivalence," The Economic and Social Review, Vol. 19, No. 1, 43-60.

Muellbauer, J. and A. Murphy (1989), "Why Has UK Personal Saving Collapsed ?", mimeo.

Sachverstandigenrat zur Begutachtung der Gesamtwirtschaftlichen Entwicklung (1981), "Vor Kurskorrekturen - Zur Finanzpol itischen und Waehrungspolitischen Situation im Sommer 1981," Special Report of July 4, 1981.

Seater, J. J. and R. S. Mariano (1985), "New tests of the lyfe cycle and tax discounting hypothesis," Journal of Monetary Economics, Vol. 15, No. 2, March, 195-215.

Thygesen, N. (1985), "The Phasing-out of Exchange Controls in Denmark," Skandinaviska Enskilda Banken Quarterly Review, 3, 59-65. 


\section{APPENDIX}

1. The response of private consumption to fiscal and monetary policy

Consider the consumption function proposed by Blanchard (1985):

$$
C(t)=(p+\theta)[H(t)+K(t)+D(t)] \text {. }
$$

where $1 / p$ is the horizon index ( $p \rightarrow 0$ being the Ricardian case of infinite horizon consumers), $H(t)$ is human capital, $K(t)$ is private weal th net of government debt, and $D(t)$ is the market value of government debt, measured in units of consumption goods. Human capital is the present discounted value of after-tax labor income, discounted at the subjective rate of the representative household, $p+\theta$ :

$$
H(t)=\int_{t}^{\infty} Y(s) e^{-(r+p)}(s-t) d s-\int_{t}^{\infty} T(s) e^{-(r+p)(s-t)} d s
$$

where the real interest rate $r$ is assumed to be constant.

To highlight the role of a long maturity of the debt, we assume that public debt consists of $B$ consols, each paying 1 dollar per period. Using the government budget constraint, the real value of debt, i.e. the discounted value of the flow of coupons on the $B$ consols (measured in units of consumption), equals the discounted value of future real budget surpluses: 


$$
D(t)=\int_{t}^{\infty} e^{-r(B-t)}\left(B e^{-\pi(B-t)}\right) d s=\int_{t}^{\infty}[T(s)-G(s)] e^{-r(B-t)} d s .
$$

Using these three equations, we can analyze the response of consumption to changes in current taxes $T(t)$, in the inflation rate $\pi$, in the real interest rate $r$ and in permanent spending $G^{P}(t)$, defined as the annuity value of the future discounted flow of real government spending:

$$
G^{D}(t)=r \int_{t}^{\infty} G(s) e^{-r(s-t)} d s
$$

As shown by Blanchard (1982), if the horizon of consumers is finite $(p>0)$ consumption falls when, for given $G^{P}(t)$, the government raises taxes temporarily, offsetting such an increase by a tax cut at some future date $t+\tau$, :

$$
\frac{\delta C(t)}{\delta T(t)}=-(p+\theta)\left(1-e^{-p \tau}\right)<0 .
$$

In both equations (5) and (6) the effect on consumption is an increasing function of $p$ : the shorter the horizon of consumers, the larger the fall in consumption in response to higher transitory taxes, or inflation. With incomplete tax discounting and long-term nominal debt, also an increase in inflation reduces consumption, since higher inflation decreases the market value of nominal debt $D(t)$ by more than it increases human capital $H(t)$. Assuming that the increase in $\pi$ is permanent and that the corresponding reduction in taxes will be concentrated at some future date $t+\tau$, the effect is: 
(6)

$$
\frac{\delta C(t)}{\delta \pi}=-(p+\theta) \frac{B}{(r+\pi)^{2}}\left(1-e^{-p \tau}\right)<0 .
$$

The effect of an increase in the real interest rate $r$, instead, is always negative, whether the horizon of consumers is infinite $(p=0)$ or not. However, in the presence of $f$ inite horizons, the negative effect of a $r$ ise in $r$ works also through the capital loss on the market value of long-term debt, that is not fully offset by a corresponding increase in human capital (due to the fall in future taxes). Assuming that real government spending and real taxes are constant at levels $G$ and $T$ respectively, and that pre-tax labor and capital income are also fixed at a level $Y$, the effect of a permanent $r$ ise in the real rate of interest is:

$$
\frac{\delta C(t)}{\delta r}=-(p+\theta) \frac{Y-G}{(r+p)^{2}}-(p+\theta) \frac{T p(2 r+p)}{r^{2}(r+p)^{2}}<0,
$$

where the term corresponding to the capital loss on long-term debt is the second one, and vanishes for $p=0$.

Finally, consider the effect of a change in current spending $G(t)$. If this is perceived as temporary, i.e. permanent spending $G^{D}(t)$ remains unchanged, it can be shown that consumption will not change, irrespective of the valie of $p$. This is because a temporary change in current spending does not affect the path of taxes. If however households regard the change in current spending as a signal of a change in permanent spending, their consumption will be affected. Suppose for instance that permanent spending increases and that in each future period $s$ taxes $T(s)$ are going to be changed by an amount equal to the change in 
permanent spending $G P(t)$. Then current consumption $C(t)$ falls:

$$
\frac{\delta C(t)}{\delta G p(t)}=-\frac{p+\theta}{r+p}<0 .
$$

Viceversa, a cut in permanent spending has an expansionary effect on current consumption. The effect of consumers' horizon $(1 / p)$ is ambiguous: on the one hand, a long horizon implies that the consumer will be around longer to enjoy lower taxes; on the other, she will have to spread the increase in her permanent income over a longer expected 1 ifetime. If the individual consumption path is flat $(\theta=r)$, these two effects cancel out, and the increase in consumption exactly matches the fall in permanent spending. A longer horizon makes the spending cut more expansionary if individual consumption is declining over time $(\theta>r)$, and less expansionary if it is increasing over time $(\theta<r)$. If $\theta>r$, an increase in permanent disposable income translates more into higher wealth accumulation than into higher current consumption; if $\theta<r$, the reverse happens.

\section{Derivation of the equation estimated in table 3}

The equation is derived along the lines of Hayashi (1982). Aggregate consumption behavior is characterized by the consumption function:

$$
C(t)=\theta[A(t)+H(t)]+B D(t)+\mu Y(t)+u(t)
$$

where $A(t)$ is real and financial wealth net of public debt, $H(t)$ is human 
capital, $D(t)$ is public debt, $Y(t)$ is personal disposable income and $u(t)$ is a white noise disturbance that captures transitory consumption shocks arising from preference shifts and measurement errors. The parameter $\beta$ on public debt can be smaller than the parameter $\theta$ on other forms of wealth to reflect the degree of tax discounting by the private sector $(\beta=0$ in the Ricardian case). The parameter $\mu$ measures the share of income accruing to consumers who do not behave according to the permanent income hypothesis, due to liquidity constraints or myopia, and simply consume all their disposable income.

The law of motion of human capital is:

$$
H(t)=(1+\delta)[H(t-1)-w(t-1)]+e(t)
$$

where $\delta$ is the discount rate that consumers apply to their future after-tax labor income $w(t)$, and $e(t)$ is the revision of the value of human capital -- a white noise error under rational expectations. An unexpected fall in permanent taxes at time $t$ leads to a revision of the PDV of future after-tax earnings $H(t)$ and thus to a positive realization of $e(t)$.

Equation (10) can be used in (9) to substitute out the unobservable $H(t)$, obtaining the equation estimated in table 3 :

$$
\begin{aligned}
C(t)= & (1+\delta) C(t-1)+\theta\{A(t)-(1+\delta)[A(t-1)+w(t-1)]\} \\
& +B[D(t)-(1+\delta) D(t-1)]+\mu[Y(t)-(1+\delta) Y(t-1)]+v(t) .
\end{aligned}
$$

The error term $v(t)=u(t)-(1+\delta) u(t-1)+\theta e(t)$ reflects current and lagged shocks to transitory consumption, $u(t)$, and revisions of human capital and 
permanent taxes, $e(t)$. Due to the non-linear restrictions among the coefficients and to the correlation between $A(t), Y(t)$ and $v(t)$, the equation must be estimated with NLIV, using variables in the information set of consumers at time $t-1$ as instruments. The $M A(1)$ component involving $u(t)$ can lead to serial correlation in the error term, which in turn can make these instruments endogenous (see Hayashi 1982); however, in our estimates this problem can be neglected, since the sample autocorrelation of the residuals is not significantly different from zero.

To the extent that a reduction in current spending is perceived by households as permanent, it will translate into an unexpected increase in the ir human capital, $H(t)$, and thus into a positive $e(t)$. Thus we expect changes in spending, if permanent, to correlate negatively with the estimated consumption residual $v(t)$, via its component $e(t)$. 